\title{
Characterization of the Human Thymic Microenvironment: Lymphoepithelial Interaction in Normal Thymus and Thymoma
}

\author{
H. K. Müller-Hermelink, A. Wilisch, A. Schultz and A. Marx \\ Department of Pathology, University of Würzburg, Würzburg, Germany
}

Received January 22, 1997

Summary. Recent advances in tissue culture technology and molecular biology have extended our understanding of the functional morphology of the thymus. The importance of a crosstalk between lymphoid cells and stroma has been appreciated as a prerequisite for the normal development of both. The network of direct cellular interactions and soluble factors comprising part of the microenvironment is far from being elucidated but the highly ordered thymic architecture clearly plays a pivotal role in normal thymic function. Insight into the genetic control of stroma development is only emerging while knowledge on the genetic control of the various steps in $T$ cell development is already advanced and rapidly expanding.

The present paper gives an overview on the cellular components and matrix molecules of the human thymic microenvironment and their development during ontogeny. The intrathymic cytokine network is shortly reviewed. Special emphasis is put on molecules mediating lymphoepithelial interactions that are necessary for the expansion and early selection of immature thymocytes from precursor cells and for the generation of an MHC restricted and self tolerant $T$ cell repertoire by positive and negative selection. Considering these physiological mechanisms we summarize the molecular pathology of the microenvironment and lymphocyte/ stroma interactions in thymic epithelial tumors (thymomas). Finally, a pathogenetic model for paraneoplastic myasthenia gravis is given. We suggest abnormal autoantigen-specific positive selection of naive $T$ cells as the essential molecular mechanism by which thymomas contribute to the autoimmunization against the acetylcholine receptor and other muscle proteins.

The microenvironment of the normal human thymus is provided by a complex network of stromal elements: epithelial and mesenchymal cells and the extracellular matrix. To be optimally functional for thymopoiesis the components of the microenviron- ment are arranged to form a unique architecture with distinct subcapsular, cortical and medullary compartments confined and partially separated by the capsule, interlobular septae and perivascular spaces. Within the microenvironment thymopoiesis requires communication between thymocytes and stroma by receptor/ligand mediated cell-cell and cell-extracellular matrix contacts, interleukines and possibly neuropeptides to provide an MHC-restricted and self-tolerant $\mathrm{T}$ cell repertoire. Thymomas are epithelial tumors that retain thymus-like features and exhibit an unrivaled frequency of paraneoplastic autoimmune phenomena among human neoplasms. The neoplastic transformation of the epithelial component in thymomas is associated with abnormalities of the microenvironment concerning architecture, cellular composition and thymocyte/stroma interactions. Microenvironmental abnormalities result in an abnormal intratumorous $\mathrm{T}$ cell development and have been considered to contribute to the pathogenesis of paraneoplastic autoimmunity, particularly myasthenia gravis. Here we focus on recent findings concerning interactions between epithelial cell and thymocytes in the normal human thymus and in thymomas and suggest a molecular mechanism explaining why thymomaassociated thymopoiesis is inefficient and might be non-tolerogenic with respect to a limited number of autoantigens.

Architecture and Constituents of the Microenvironment of the Normal Human Thymus

The normal thymic microenvironment consists of nonlymphoid stromal cells and the extracellular matrix. The majority of stromal cells are epithelial 
cells derived from the endoderm of the 3rd pharyngeal pouch and the cervical vesicle that develops from the 2nd, 3rd and 4th branchial cleft ectoderm (VON GAUDECKER, 1986). In humans thymic primordia are first present at the 7th week of gestation (HAYNES, 1984) with a distinct organization into a peripheral and central cell layer at the 8th week of gestation (VON GAUDECKER and MÜLLER-HERMELINK, 1980). Thymic mesenchymal cells are derived from the embryonic mesoderm forming the capsule, interlobular septae and vessels (BOYD et al., 1993). As shown in the mouse, both epithelial and mesenchymal elements are necessary for $\mathrm{T}$ cell development (ANDERSON et al., 1993, 1994).

The first $\mathrm{T}$ cell progenitors colonize the human thymus at the 8th week of gestation (VON GAUDECKER, 1986). The nature of the $T$ cell progenitor colonizing early human thymic primordia and adult thymuses has not yet been resolved (reviewed by SPITS et al., 1995). At present experimental findings favor the view that the earliest progenitor in humans is not the pluripotential stem cell typical of bone marrow but a multipotential committed stem cell with a $\mathrm{CD} 34^{+}$ $\mathrm{CD} 38^{\text {low }} \mathrm{CD} 45 \mathrm{RA}^{+}$Thy $1^{-}$phenotype and the potential to give rise to $\mathrm{T}$ and natural killer (NK) cells (SANCHEZ et al., 1994; SpITS et al., 1995) and dendritic cells in mice (ARDAVIN et al., 1993) and man (RES, 1996). Colonization of the thymus primordia by $\mathrm{T}$ cell progenitors is necessary for the further development of the thymic microenvironment including the compartmentalization into cortex and medulla and the development of Hassall's corpuscles as detectable at the 15th week of gestation (HAYNES, 1984; HAYNES and HeINLY, 1995). The necessity for colonization is obvious in patients with particular forms of severe combined immunodeficiency (SCID) and SCID mice that exhibit lymphocyte-poor dysplastic thymic rudiments devoid of distinctive medullary areas and Hassall's corpuscles (NEZELOF, 1992). "Dysplasia" in almost all these cases does not arise from an epithelial dysfunction but from various intrinsic $T$ cell defects (see below). As a consequence normal thymic architecture and function is achieved after wild type bone marrow transplantation. These findings support the concept that a cross-talk between thymocytes and epithelial cells is necessary for thymopoiesis and differentiation of the microenvironment though not for its initial formation (RITTER and BOYD, 1993; VAN

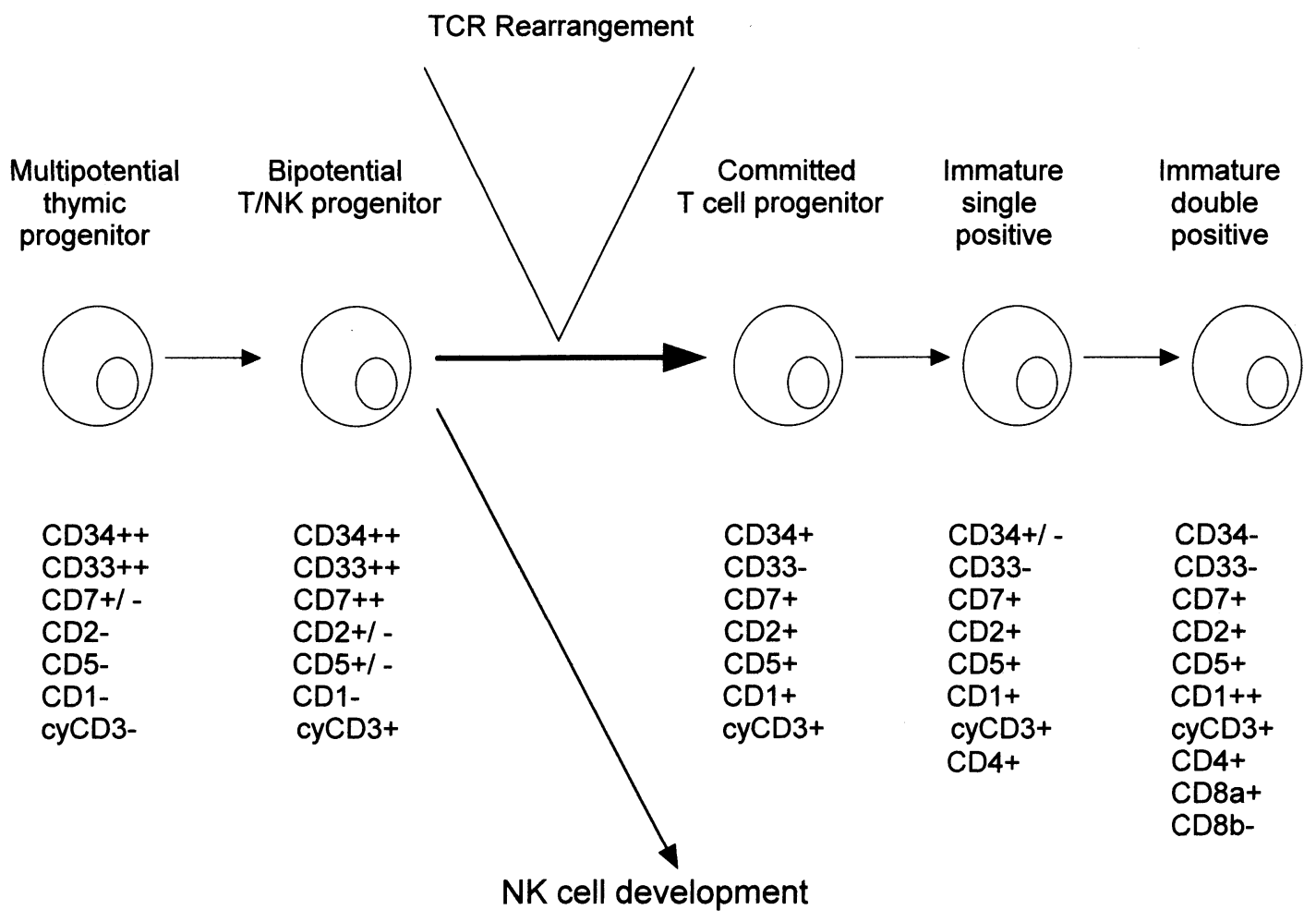

Fig. 1. Model of early T cell development in the human thymus as defined by multicolor FACS analysis (SPITS et al., 1995). 
EwIJK et al., 1994; KISIELOW and vON BOEHMER, 1995; NEHLS et al., 1996)

The epithelial cells of the thymic microenvironment are very heterogeneous (Boyd et al., 1993). Distinct cell types occur in the subcapsular area, cortex proper, medulla and Hassall's corpuscles (Fig. 1). By electron microscopy six types (type 1-6) of epithelial cells have been discriminated (VAN DE WIJNGAERT, 1984) considering shape and electronlucency. The subcapsular type 1 epithelial cells that comprise the vast majority of cells with neuroendocrine features (DARDENNE and SAVINO, 1994; MAG-GIANO et al., 1994) are usually MHC (major histocompatibility complex) class II negative (VON GAUDECKER, 1986). By contrast type 2-4 (cortical) and type 5 and 6 (medullary) epithelial cells are MHC class I and II positive (BOFILl et al., 1985; VON GAUDECKER, 1986). Thymic nurse cells (TNCs) (WEKERLE and KETELSEN, 1980) in humans are specialized type 2 or 3 cells forming lymphoepithelial complexes by emperipolesis (RITTER et al., 1981; VAN DE WIJNGAERT et al., 1983). Since TNC contain mostly immature $\mathrm{CD} 4^{+}$ $\mathrm{CD} 8^{+}$thymocytes but also mature and mainly $\mathrm{CD} 4^{+}$ thymocytes with syngeneic reactivity (in mice) (PEN NINGER and WICK, 1992) TNCs might play a role in positive selection. There are no monoclonal antibodies specific for TNCs. By immunohistochemistry an even greater heterogeneity of thymic epithelial cells can be realized and antigenic overlaps between epithelial cells in the different thymic compartments have been detected (BOYD et al., 1993). Nevertheless, some antigenic determinants have been identified by monoclonal antibodis as characteristic of the morphologically defined thymic compartments (Table 1). Such monoclonal antibodies have proved valuable for the analysis of thymomas (WILlCox et al., 1987; KIRCHNER et al., 1992).

Macrophages are bone marrow derived constituents of the thymic microenvironment and appear in thymus primordia together with $\mathrm{T}$ cell progenitors
(JORDAN and ROBINSON, 1981; VON GAUDECKER, 1986). Macrophages are phenotypically heterogeneous (BOYD et al., 1993) with variable expression of MHC class II antigens (RITTER and CRISPE, 1992; RUCO et al., 1993). They are found throughout the thymus but occur at higher density in the cortex.

Interdigitating dendritic cells (IDC) are also bone marrow derived but can be observed only around the 12 th week of gestation when the thymus primordia become lobulated (KAISERLING et al., 1974; VON GAUDECKER and MÜlLER-HeRMELINK, 1980). IDC are MHC class II positive, occur throughout the thymus but are concentrated along the cortico-medullary junction. In humans IDC are considered the main mediators of negative selection (clonal deletion) in vivo (VANDEKERCKHOVE et al., 1992; BACHETTA et al., 1993, 1994; Schols et al., 1994).

Thymic B cells (ISAACSON et al., 1987; FEND et al., 1991) and myoid cells (KAO and DRACHMAN, 1977; WEKERLE et al., 1975, 1978) are constituents of the human thymic microenvironment restricted to the thymic medulla. Thymic B cell precursors are probably derived from immature multipotential progenitors as are thymic T, NK and dendritic cells (BARCENA et al., 1994; RES et al., 1996). They colonize the thymus very early during ontogeny (KIмоTO et al., 1989) and almost all maintain unmutated, fetal type $\mathrm{IgVH}$ genes after intrathymic maturation throughout adulthood (DUNN-WALTERS et al., 1995). Thymic B cells in mice might play a role in negative selection (MAZDA et al., 1991) but their function in humans has yet to be established (SPENCER et al., 1992). Myoid cells can be detected as early as the 8th week of gestation (VON GAUDECKER and MÜLLER-HERMELINK, 1979) and in all postnatal thymuses though in declining number with higher age (DRENCKHAN et al., 1979; KIRCHNER et al., 1986; SCHLUEP et al., 1988; GEUDER et al., 1992; BornemAnN and KirChNer, 1996). Myoid cells like extraocular and most facial muscles are not of somitic origin but derivatives of the precordal mesen-

Table 1. Monoclonal antibodies defining epithelial antigen determinants confined to the distinct thymic compartments of subcapsular epithelium, cortex, medulla, and Hassall's corpuscles in normal human thymus

\begin{tabular}{lll}
\hline Antibody & Compartment & Reference \\
\hline K-20 & Subcapsular epithelium (Type 1) & TAKEUCHI et al., 1991 \\
RFD, MR19 & $\begin{array}{l}\text { Subcapsular epithelium plus medullary } \\
\text { epithelium }\end{array}$ & $\begin{array}{l}\text { BofILL et al., 1985 } \\
\text { DE MAAGD et al., 1985 }\end{array}$ \\
MR3, MR6 & Cortical epithelium & DE MAAGD et al., 1985 \\
HTS7 & Medullary epithelium & IzON and BoYD, 1990 \\
MR13, TE-8, 15, 16 & Hassall's corpuscles & DE MAAGD et al., 1985 \\
\hline
\end{tabular}


chyme (SEIFERT and CHRIST, 1990). Their function is unknown but they may be involved in the pathogenesis of non-paraneoplastic myasthenia gravis (WeKERLE and KeTELSEN, 1977; GeUder et al., 1992; MARX et al., 1996a, 1997). Both B cells and myoid cells are usually absent from thymomas (KIRCHNER et al., 1992; MÜLLER-HERMELINK et al., 1996).

The thymic microenvironment also comprises the extracellular matrix. This consists of collagens, glycosaminoglycanes and glycoproteins, including laminin and fibronectin (SAVINO et al., 1993). Collagen type I is abundant in the thymic capsule and septae, while the basal lamina underlying type 1 epithelial cells in the subcapsular area and along perivascular spaces is composed of collagen type IV, fibronectin and laminin (BERRIH et al., 1985; LANNES-VIEIRA et al., 1991). Destruction of the basal lamina is a typical feature of the thymus in myasthenia gravis-associated thymitis (KIRCHNER et al., 1986). A fine network of extracellular matrix composed of fibronectin, collagen type IV and laminin is also detectable by reticulin stains around epithelial cells in the thymic medulla but not in the cortex, where fibronectin but not the other two components of extracellular matrix can be detected only by immunohistochemistry (RUCO et al., 1993). As this difference is maintained after neoplastic transformation reticulin stains help to distinguish thymic epithelial tumors of medullary versus cortical differentiation (MÜLLER-HERMELINK et al., 1996). Receptors for the extracellular matrix are found on thymocytes suggesting a direct role of the extracellular matrix in thymopoiesis (see below). In addition receptors for the extracellular matrix are also expressed on human thymic epithelial cells (RUCO et al., 1993) supporting the idea that the extracellular matrix may also play an indirect role in thymopoiesis by maintaining the cellular network of the microenvironment (SAVINo et al., 1993; HAYNES et al., 1995).

The functional development of the thymus is not completed until after birth in the mouse (BOYD et al., 1993; SuRH et al., 1993). Whether this is also the case in humans has not yet been evaluated.

Finally, the genetic control underlying the development and heterogeneity of the cellular components of the thymic microenvironment is in the beginning of being elucidated at least in mice (BoEHM et al., 1995). The $w h n$ gene that is characteristically inactivated in the nude mouse codes for a transcription factor that controls very early steps in the development of the thymic microenvironment prior to immigration of $\mathrm{T}$ cell progenitors (NEHLS et al., 1996). In contrast, absence of the relB gene results in developmental defects of the thymic medulla involving both a characteristic medullary epithelial subset and bone marrow derived dendritic cells (WeIH, 1995; BURKLY et al., 1995). These genetic defects might be considered as "true thymic dysplasias" of the microenvironment in contrast to "dysplasias" in primary T cell defects. Human equivalents of these primary immunodeficiencies have yet to be detected though some subtype of Nezelof's syndrome (NEZELOF, 1992) may be a good candidate for a whn deficiency state (BOEHM et al., 1995). Likewise the role of both genes in the pathogenesis of thymomas awaits investigation.

\section{Lymphoepithelial Interactions in the Normal Human Thymus during Early T Cell Development: The Pre-T Cell Receptor Complex, Cytokines, and Adhesion Molecules}

Early $\mathrm{T}$ cell development comprises the entry of immature $T$ cell progenitors into the thymus, and their proliferation and differentiation prior to positive selection. What governs the entry of thymocyte progenitors into the thymus is enigmatic so far (discussed by AURRAND-Lions et al., 1996; PATEL et al., 1995). We summarize the phenotypic stages that can be delineated by flow cytometry starting from the earliest $\mathrm{CD} 34^{+} \mathrm{CD} 3^{-} \mathrm{CD}^{-}{ }^{-} \mathrm{CD} 8^{-}$(triple negative, $\mathrm{TN}$ ) precursors to the $\mathrm{CD} 3 / \mathrm{TCR}^{10 w} \mathrm{CD}^{+} \mathrm{CD}^{+}$(double positive, DP) subset in Figure 1 (SPITS et al., 1995) because characteristic quantitative alterations in these immature thymocyte subsets occur in thymomas (see below). Some of the molecular events involved in the expansion and differentiation of immature thymocytes have been elucidated in mice. Transition from the triple negative to the double positive stage requires expression of the $T$ cell receptor (TCR) beta chain that has to associate with a $33 \mathrm{kD}$ invariant chain (preTCR) forming the preTCR complex (SAINT-RUF et al., 1994). This complex is expressed on the cell surface just before upregulation of $\mathrm{CD} 4$ while TCR alpha rearrangement is probably initiated only in the more mature $\mathrm{CD} 3^{-} \mathrm{CD} 4^{+} \mathrm{CD} 8^{-}$ subset (SPITS et al., 1995). Recently the human preTCR has been cloned (DEL PORTO et al., 1995; RAMIRO et al., 1996). The preTCR complex can deliver signals to TN thymocytes resulting in the appearance of DP cells (LEVELT et al., 1993). Signal transduction triggered by the preTCR complex involves the tyrosine kinases lck (Molina et al., 1992) and fyn (VAN OERS et al., 1996). Furthermore, some of the genes coding for transcription factors that play important roles in the most early steps of $\mathrm{T}$ cell differentiation have been identified in mice (reviewed by TING et al., 1996). On the other hand it is so far unclear which ligand(s) in the thymic microenvironment trigger the preTCR 


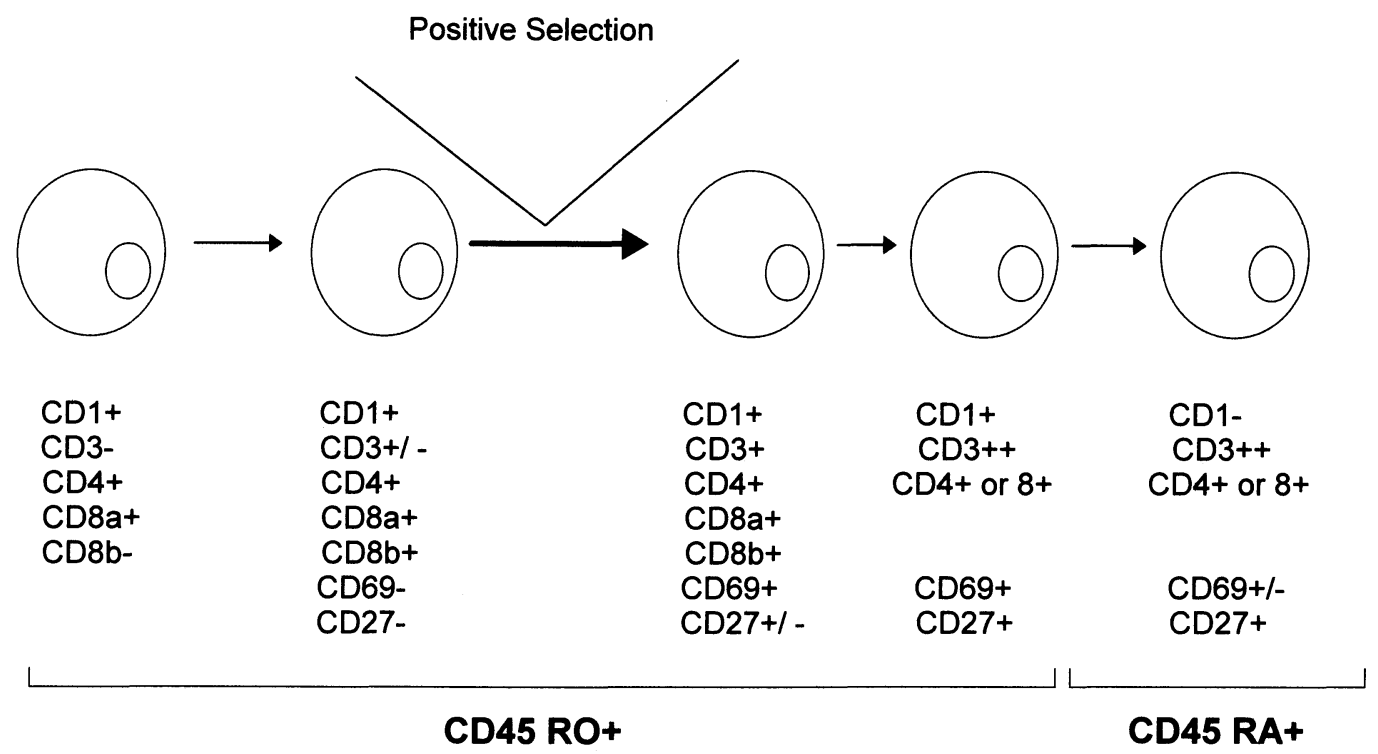

Fig. 2. Model of $\mathrm{T}$ cell development in the human thymus: $\mathrm{T}$ cell phenotypes as defined by multicolor FACS analysis just before and following positive selection (SPITS et al., 1995).

complex in vivo (OWEN and VenKitARAMAN, 1996).

In addition to preTCR complex signaling cytokines might play a role in human early $\mathrm{T}$ cell development (SPITS et al., 1995; LERNER et al., 1996). A wealth of cytokines have been identified in the human thymic microenvironment. IL-1, IL-3, IL-4, IL6, IL-7, IL-8, G-CSF, M-CSF, GM-CSF, TNF-alpha, TGF-beta-1 and SCF (C-kit ligand) were described as in vitro products of various epithelial subsets (HAYNES et al., 1990; Dalloul et al., 1991; GAly et al., 1991, 1992, 1993; RoPKE and EibRoEND, 1992; MEILIN et al., 1992; RitTER and BOYD, 1993; FERNANDEZ et al., 1994). Of particular interest is the production of IL-7 but not of IL-2, 3 and 4 by cortical type human epithelial cell lines (FERNANDEZ et al., 1994). Several cytokines influence the production of each other and of adhesion molecules via cytokine receptors on thymic epithelial cells (reviewed by RITTER and BOYD, 1993). However, knock out experiments in mice and circumstantial evidence from humans (concerning IL-2, reviewed by SPITS et al., 1995) suggest that at least IL-2, 4, 6 and IFN-gamma are not critical for thymic $\mathrm{T}$ cell and microenvironment development while lack of the common gamma chain of the IL-2, 4, 7 and IL-15 receptor abrogates early thymopoiesis resulting in X-chromosome-linked SCID (Voss et al., 1994). Based on this latter finding it can be concluded that IL-7 must be essential also for thymic T and NK cell development in humans (GRABSTEIN et al., 1993; Hozumi et al., 1994). The molecular events triggered by IL-7 during early T cell development have still to be elucidated. It is also not clear whether the concerted action of IL-7 plus SCF that is necessary for optimal proliferation of triple negative thymocytes in vitro (MATSUZAKI et al., 1993) is also required in the human thymic microenvironment in vivo. Furthermore, it is unresolved whether epithelial-derived TGF-beta regulates the transition of immature CD3$\mathrm{CD} 4^{+} \mathrm{CD}^{-}$thymocytes to double positive cells in humans as it regulates the respective development in mice (TAKAHAMA et al., 1994). Whether cytokines play a role in the $T$ cell selection processes, particularly in negative selection, is presently under investigation (FoY et al., 1995; SPITS et al., 1995; LERNER et al., 1996).

Adhesion/costimulatory molecules are indispensable for the regulation of mature $\mathrm{T}$ cell activation (ClARK and LEDBETTER, 1994). Evidence that lymphoepithelial interactions by adhesion molecules (SINGER et al., 1990; MARX et al., 1994) including integrins (ZUTTER, 1991; RUCO et al., 1993), may contribute to early $\mathrm{T}$ cell development is restricted to in vitro mouse systems concerning the LFA-1/ICAM-1 (FINE and KRUISBEEK, 1991) and VLA-4/Fibronectin receptor/ligand pairs (UTSUMI et al., 1991). Other receptor/ ligand lymphoepithelial interactions like CD2/LFA-3 
obviously play no role during early thymopoiesis (KILLEEN et al., 1992) and VCAM-1, another ligand for VLA-4, seems to be restricted to macrophages and vessels in the normal human thymus (RUCO et al., 1993; MARX et al., 1994). The distribution of beta-1 (VLA) integrins other than VLA-4 has also been reported in the human thymus (LANIER et al., 1986; ZUTTER 1991; GIUNTA et al., 1991; RUCO et al., 1993; FERNANDEZ et al., 1994) and is summarized in Table 2. Integrins exhibit a stable expression during thymic ontogeny. However, their role in thymic microenvironmental development and human thymopoiesis has still to be defined (SAVINO et al., 1993; FERNANDEZ et al., 1994).

\section{Positive and Negative Selection and Late Thymo- cyte Development: Lymphoepithelial Interaction by TCR/MHC, Costimulatory Molecules and Apoptosis-Related Proteins}

The $\mathrm{T}$ cell repertoire is shaped by positive and negative selection (VON BOEHMER, 1994; NOSSAL, 1994). Positive selection is necessary for the maturation of double positive thymocytes into MHC restricted mature single positive thymocytes. Negative selection deletes most potentially autoaggressive $T$ cells that efficiently recognized self antigens. Both positive and negative selection require interactions of the TCR (on thymocytes) with complexes composed of MHC molecules and self peptide that are exposed on cells of the thymic microenvironment. That the same receptor/ligand pair can mediate either sur- vival signals (positive selection) or delection by apoptosis (negative selection) is the result of different levels of avidity between TCR and MHC/peptide complexes (HoGQUIST et al., 1993; ALLEN, 1994; ASHTONRICKARDT and TONEGAWA, 1994). High levels of avidity result in delection of potentially autoaggressive thymocytes, while intermediate levels of avidity result in $\mathrm{MHC}$ restriction and rescue from apoptosis (positive selection) by survival signals.

Positive selection in vivo is mediated by thymic cortical epithelial cells while studies from bone marrow transplanted SCID patients demonstrate that negative selection requires dendritic cells (reviewed by SPITs et al., 1995). However, thymic epithelial cells may induce non-deletional tolerance by anergizing thymocytes (VANDEKERCKHOVE et al., 1992). Since this type of tolerance can be broken by IL-2 (ScHOLS et al., 1994) it is potentially important also for thymoma associated autoimmunity though this has yet to be investigated.

The signaling events involved in positive section have partially been resolved in mice, and include CD45 (KishinARA et al., 1993), Zap-70 (NEGISHI et al., 1995), the p21ras and MAP kinase pathway (SwAN et al., 1995; ALBEROLA et al., 1995), calcineurin (WANG et al., 1995), and the Vav protein (FISCHER et al., 1995). Whether targets of these signaling elements are members of the Bc12 family (MA et al., 1995) or transcription factors like Ets-1 (BoRIEs et al., 1995) has to be evaluated. In humans ZAP-70 is required for the positive selection only of $\mathrm{CD} 8^{+}$cells (ELDER et al., 1994; ARPAIA et al., 1994). How interaction of TCR

Table 2. Expression of very late activation (VLA) antigens ( $\beta 1$ integrins) and other adhesion molecules relevant for thymocyte/stroma interaction in the normal human thymus (RUCO et al., 1993; MARX et al., 1994)

\begin{tabular}{lccccc}
\hline $\begin{array}{l}\text { Adhesion } \\
\text { molecule }\end{array}$ & $\begin{array}{c}\text { Subcapsular } \\
\text { epithelium }\end{array}$ & $\begin{array}{c}\text { Cortical } \\
\text { epithelium }\end{array}$ & $\begin{array}{c}\text { Medullary } \\
\text { epithelium }\end{array}$ & Macrophages & Endothelium \\
\hline alpha $1^{1,2}$ & - & - & - & - & + \\
2 & + & + & + & - & + \\
3 & + & - & + & - & + \\
5 & - & - & - & + & + \\
6 & + & - & $+/-$ & - & + \\
\hline VCAM-1 & - & - & - & + & + \\
ICAM-1 & $+/-$ & + & + & + & - \\
LFA-3 & - & - & $+/-$ & + & + \\
B7-1(BB1) & - & - & $+/-$ & - & - \\
\hline
\end{tabular}

${ }^{1}$ VLA4 is expressed on immature and mature thymocytes strongly and moderately, respectively (MARX et al., 1994)

${ }^{2}$ Human cortical type thymic epithelial cells express all $\beta 1$ integrins and LFA-3 in vitro (FERNANDEZ et al., 1994) 
with either an MHC class I or II molecule (plus peptide) elicits the differential development of either $\mathrm{CD} 8{ }^{+}$or $\mathrm{CD} 4^{+}$single positive mature $\mathrm{T}$ cells ("lineage commitment") is still a matter of debate (LUCAS and GERMAIN, 1996).

While positive selection may function by TCR/ MHC interaction alone, thymocytes require more than TCR ligation with $\mathrm{MHC} /$ peptide complexes to undergo negative selection (reviewed by OwEN and VENKITARAH, 1996; LERNER et al., 1996). While thymocyte/stroma interactions via Fas/FasL (SINGER and ABBAS, 1994; ADACHI et al., 1996) are probably dispensable in vivo, CD30/CD30L (AMAKAWA et al., 1996) and CD40/CD40L (Foy et al., 1995) and CD28/ B7-1 (Kishimoto et al., 1996) seem to be important (as shown in mice). The function of the Fas antigen intensively expressed on human normal and neoplastic thymic epithelial cells (ONODERA et al., 1996; KAWANAMI, personal communication) has still to be determined. Likewise, the significance of the intense cross-talk between thymocytes and the thymic microenvironment for thymocyte deletion involving various cytokines awaits clarification (LERNER et al., 1996). Only preliminary data are available about the signaling pathways mediating negative selection, again only in mice (CALNAN et al., 1995; LERNER et al., 1996; ANDERSON et al., 1996).

With respect to the pathogenesis of autoimmunity it has to be stressed that the predominant form of intrathymic cell death is not delection (negative selection) but "death by neglect" of thymocytes that undergo neither positive nor negative selection in the thymic microenvironment because of defective TCR/ MHC interaction (SURH and SPRENT, 1994). Whether this type of apoptosis shares molecular signals with deletion-induced apoptosis is unknown (LERNER et al., 1996). Since "death by neglect" may be a tolerogenic mechanism for antigens/peptides not presented by MHC molecules in the thymus (MARX et al., 1990), a change of the thymic endogenous peptide pool or its presentation may contribute to the generation of autoaggressive $\mathrm{T}$ cells in thymoma (see below). The thymocyte subsets that can be distinguished by FACS

Table 3. Expression of VLA antigens and adhesion molecules in thymomas (RUCO et al., 1993; MARX et al., 1994; MARX et al., unpublished)

\begin{tabular}{cccc}
\hline $\begin{array}{c}\text { Adhesion } \\
\text { molecule }\end{array}$ & $\begin{array}{c}\text { Medullary } \\
\text { thymoma }\end{array}$ & $\begin{array}{c}\text { Mixed } \\
\text { thymoma }\end{array}$ & $\begin{array}{c}\text { Cortical } \\
\text { thymoma* }\end{array}$ \\
\hline alpha 1 & - & - & - \\
2 & +++ & +++ & $+/++$ \\
3 & +++ & +++ & $-/+$ \\
5 & - & - & - \\
6 & + & ++ & $-/+$ \\
\hline VCAM-1 & + & - & - \\
ICAM-1 & +++ & +++ & +++ \\
LFA-3 & ++ focally) & $-/+$ & +++ \\
B7-1(BB1) & + & $+/+$ & $+/++$ \\
\hline
\end{tabular}

* Similar expression in well differentiated thymic carcinoma (WDTC)

Table 4. Classification of thymic epithelial tumors (TET) according to MüLlER-HERMELINK et al. (1995). Association with myasthenia gravis (MG) and expression of MG-associated $160 \mathrm{kD}$ neurofilament NF-M containing AChR and titin epitopes (MARX et al., $1996 \mathrm{a}, \mathrm{b}$ )

\begin{tabular}{|c|c|c|c|c|}
\hline Tumor & $\begin{array}{c}\text { Cases } \\
\text { investigated }^{1}\end{array}$ & $\begin{array}{l}\text { Frequency } \\
\text { of MG }\end{array}$ & $\begin{array}{l}\text { Tumors with } \\
\text { NF-M }\end{array}$ & $\begin{array}{l}\text { Tumors } \\
\text { without NF-M }\end{array}$ \\
\hline \multicolumn{5}{|l|}{ Organotypic TET } \\
\hline Medullary thymoma & 10 & $30 \%$ & 0 & 3 \\
\hline Mixed thymoma & 33 & $40 \%$ & 1 & 14 \\
\hline $\begin{array}{l}\text { Predominantly cortical } \\
\text { thymoma }\end{array}$ & 15 & $40 \%$ & 6 & 5 \\
\hline Cortical thymoma & 81 & $69 \%$ & 14 & 1 \\
\hline $\begin{array}{l}\text { Well differentiated } \\
\text { thymic carcinoma }\end{array}$ & 33 & $79 \%$ & 11 & 0 \\
\hline Non-organotypic TET & 24 & $0 \%$ & 4 & 1 \\
\hline Tumors with MG & & & 30 & 8 \\
\hline Tumors with MG & & & 4 & 16 \\
\hline
\end{tabular}

${ }^{1}$ All cases available (frozen and paraffin) 


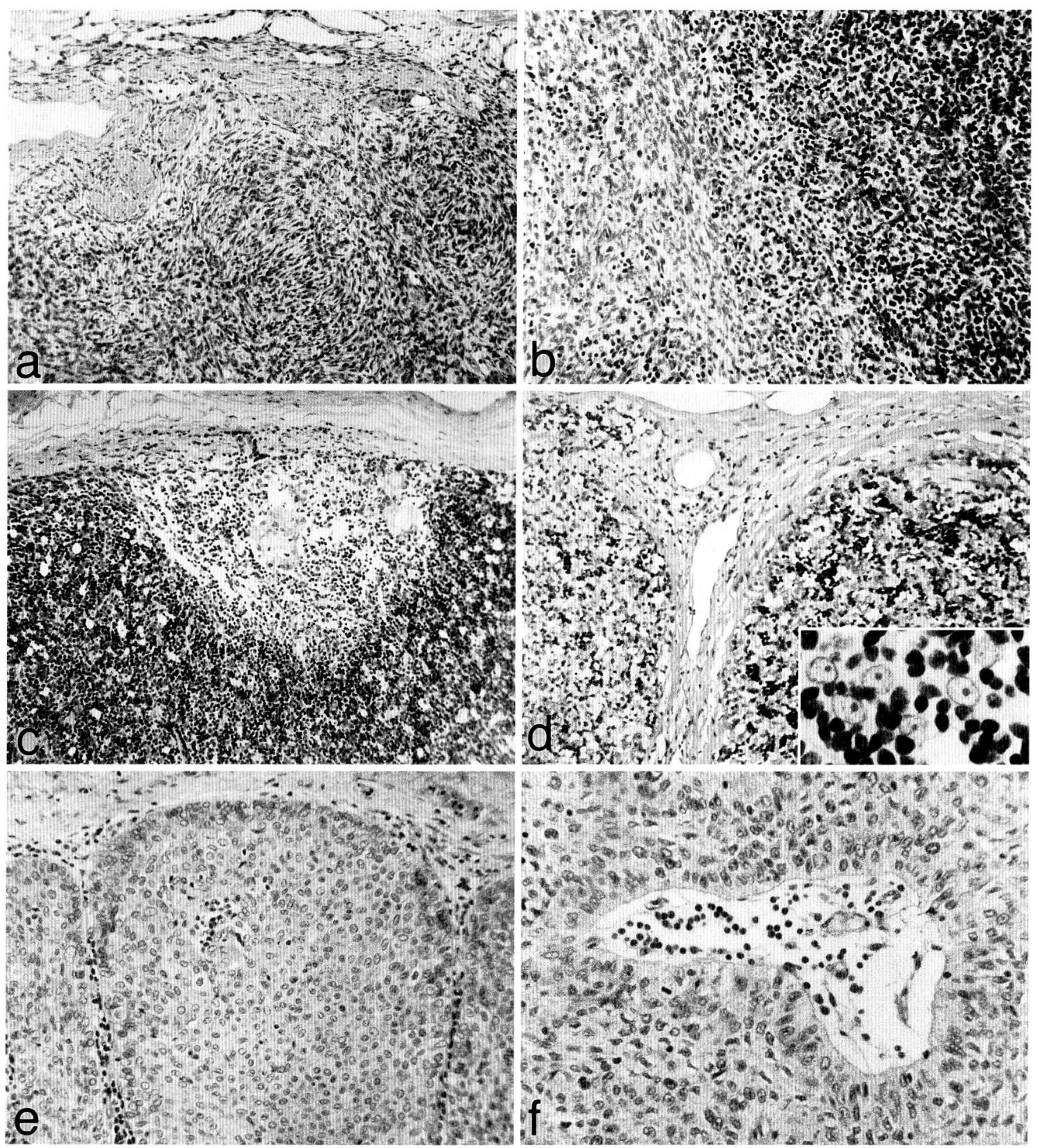

Fig. 3. Histology of organotypic thymic epithelial tumors according to the "histogenetic" or "functional" classification (Table 4). a. Medullary thymoma with spindle shaped epithelial cells, characteristic cysts and few lymphocytes. b. Mixed thymoma with sharp transition between a lymphocyte poor spindle cell area and a lymphocyte rich area. The large epithelial cell nuclei and nucleoli that are characteristic of cortical thymomas are absent from mixed thymomas. c. Predominantly cortical (organoid) thymoma with well developed medullary and cortical areas. The position of the medullary area adjacent to the capsule in this tumor is a characteristic architectural abnormalities distinguishing this tumor type from the normal thymus. d. Cortical thymoma with lobular architecture, roughly balanced number of immature lymphocytes and epithelial cells with characteristic nuclear and nucleolar morphology (Inset). e. Well differentiated thymic carcinoma (WDTC) with characteristic lobular, solid architecture and prevalence of epithelial cells with slight nuclear atypia. f. Characteristic palisading of epithelial cells around a perivascular space in WDTC. Hematoxylin-eosin, a-d: $\times 100$, Inset in $\mathrm{d}: \times 400, \mathrm{f}: \times 250$ 
analysis after positive selection are given in Figure 2 (SPITs et al., 1995).

\section{Thymomas}

Thymomas are thymic epithelial tumors - in contrast to thymus-derived T or B cell lymphomas (ROSAI and Levine, 1976; MÜller-HermelinK et al., 1996). "Organotypic" (i.e. "thymus-like") morphological and functional features (KIRCHNER et al., 1992) distinguish thymomas as unique thymic tumors from other tumors also arising in the thymus but not unique to it like category II thymic carcinomas, germ cell neoplasms or mesenchymal tumors (reviewed by RoSAI, 1996; MÜlLER-HermelinK et al., 1996). The most characteristic functional feature considered as "organotypic" is the capacity of thymomas to provide homing for immature $\mathrm{T}$ cell detectable by antiCD1 or CD99 antibodies (KIRCHNER et al., 1992; CHAN et al., 1995). In addition, only thymomas but not other thymic neoplasms elicit myasthenia gravis or other autoimmune diseases.

Thymoma classification has been one of the most controversial fields in pathology as discussed recently (ROSAI, 1996; MÜllER-HERMELINK et al., 1996). MÜLlERHERMELINK and coworkers have proposed a "histogenetic" or "functional" classification (Table 4, Fig. 3) considering the morphological resemblance of the various neoplastic epithelial cell types to their counterparts in the normal thymus and the differential functional capacity to provide homing for or promote proliferation and differentiation of immature thymocytes (MARINo and MÜLler-HeRMELINK, 1985; MÜLLERHERMELINK et al., 1996). Compared to earlier classifications (reviwed by ROSAI, 1996) this novel classification has been proven to be highly reproducible (CLOSE et al., 1995), to be of prognostic relevance (Quintanilla et al., 1993), to correlate with the occurrence of autoimmunity (Table 4), immunohistological features (MARX et al., 1996a) and intratumerous thymocyte differentiation (NENNINGER et al., 1996).

\section{Abnormal Composition of Thymoma Microenviron- ments}

The neoplastic transformation of the epithelium in thymomas is the basis for the disturbance of the normal compartmentalization into subcortical, cortical and medullary areas and of abnormal epithelial cell properties (see next paragraph). However, neoplastic epithelial transformation is associated also with alterations of the other cellular constituents of the microenvironment. In particular, there is a dramatic paucity of thymic B cells in thymomas (FEND et al., 1993) but it is unknown whether thymic B cell deficiency compromises tolerance induction (SPENCER et al., 1992). S100+ interdigitating dendritic cells (IDC) (a minority of which is $\mathrm{CD}^{+} \mathrm{a}^{+}$) are thought to be the main physiological effectors of negative selection (SPITS et al., 1995). IDC seem also to be reduced in some but not all thymomas (CHILOSI et al., 1984; LAURIOLA et al., 1984; MÜLLER-HERMELINK, 1986; WillCoX et al., 1987; TAKEUCHI et al., 1995). An association between a reduced number of IDC and autoimmune phenomena has not been found (LAURIOLA et al., 1984; KRAUS et al., 1988) though this may require further analysis (LERNER et al., 1996). Finally, thymic myoid cells, expressing the myasthenia gravis-relevant antoantigen acetylcholine receptor (AChR), are usually absent from thymomas (KIRCHNER et al., 1986), though rare benign thymomas (reviewed by ROSAI, 1996) and also high grade thymic carcinomas (unpublished) may exhibit increased numbers. Since it is not known, whether myoid cells normally play a role in AChR-specific negative selection, the significance of their absence for paraneoplastic antoimmunity remains to be investigated. Not only the cellular components of the neoplastic thymic microenvironment, but also constituents of the extracellular matrix exhibit abnormalities in thymomas. As a general tendency there is increased deposition of fibronectin, laminin and collagen type IV in mixed and medullary thymomas as compared to the normal thymus while the expression of these matrix molecules in cortical thymomas is very low as it is in the normal cortex (RUCO et al., 1993). Whether these abnormalities contribute to paraneoplastic autoimmunity is unknown (VON BOEHMER, 1994).

"Homing molecules" expressed by endothelial cells, the extracellular matrix or perivascular stromal cells (like VLA-6, CD44R or Vanin-1, reviewed by PATEL and HAYNES, 1994; AURRAND-Lions et al., 1996) have not yet been investigated in thymomas.

Future investigations of the abnormal microenvironment of neoplastic thymuses will have to consider the so far neglected cytokine network of thymomas.

\section{Abnormal Epithelium in Thymomas}

The terms "medullary thymoma" or "cortical thymoma" applied by the functional/histogenetic thymoma classification (Table 4) could suggest that the various thymoma subtypes are neoplastic expan- 
sions of one of the various thymic epithelial cell subsets encountered in the normal thymus. However, this is not the case, although some morphological similarities between neoplastic epithelial cells and their normal counterparts exist (MARINO and MÜLLERHERMELINK, 1985). By contrast, epithelial cells of thymomas more closely resemble thymic epithelial cell subsets encountered at various maturational stages during thymus ontogeny (KRAUS et al., 1988). Antigenic heterogeneity in a given tumor has been explained by suggesting maturational arrest at various developmental stages of the progeny of a common (clonal) tumor stem cell (WiLlcox et al., 1987). A common and characteristic theme probably related to the heterogeneous state of "immaturity" might be the finding that features defining the distinct medullary and cortical compartments in the normal adult thymus are combinedly expressed by epithelial cells of thymomas (MÜLLER-HERMELINK et al., 1996). This finding concerns morphological features like the expression of keratins (MOKHTAR et al., 1984; CHILOSI et al., 1984; MÜller-HermelinK, 1986; WillCoX et al., 1987), neurofilaments (MARX et al., 1996b), adhesion molecules (RUCO et al., 1993), and costimulatory ligands for thymocyte receptors (MARX et al., 1994; GILHUS et al., 1995) but particularly functional features; in spite of partial medullary type immunohistochemical properties most thymomas support the development of immature thymocytes like the normal cortex (CHILOSI et al., 1984; MÜLLER-HERMELINK, 1986; WillCox et al., 1987). Vice versa epithelial cells derived from cortical thymomas can present soluble antigen to mature $\mathrm{CD} 4^{+} \mathrm{T}$ cells (MARX et al., 1994; GILHUS et al., 1995) though this is a property restricted to medullary type epithelium in the normal thymus (KASAI et al., 1996).

With respect to the triggering of paraneoplastic autoimmunity abnormal expression of molecules mediating lymphoepithelial interactions in thymomas have attracted much attention. Interestingly there is a tendency for upregulation of adhesion and costimulatory molecules in thymomas as summarized in Table 3. This latter statement concerns beta-1 integrins like VLA-2, 3 and 6 (RUCO et al., 1993), CD40 (SCHULTZ et al., 1996), ICAM-1, LFA-3 and B7-1 (MARX et al., 1994; GILHUS et al., 1995). While upregulation of costimulatory molecules could principally suggest a higher susceptibility of mature $T$ cells for antigen-specific activation (CLARK and LEDBETTER, 1994; MARX et al., 1994), experimental evidence does not support intratumorous $T$ cell activation as a mechanism of autoimmunization in thymoma-associated autoimmunity (SCHULTZ, 1997). On the contrary, extrapolation from mice suggests that upregulation of CD40 (SchUlTZ et al., 1996) or B7-1 in conjunction with ICAM-1 in thymomas (MARX et al., 1994) may either enforce negative selection (Foy et al., 1995; KIsнiмото et al., 1996) or entail inefficient positive selection (Kishimoto et al., 1996). Both effects would counteract autoimmunization (ScHULTZ et al., 1996).

On the contrary, downregulation of MHC class II expression by epithelial cells of most thymomas is a very characteristic though not constant finding (MOKHTAR et al., 1984; CHAN et al., 1984; WiLlCOX et al., 1987; KIRCHNER et al., 1992). Although a clear-cut correlation between MHC class II expression and the occurrence of myasthenia gravis has not been established (CHILOSI et al., 1984; WILlCoX et al., 1987) this finding may only demonstrate that different mechanisms of tolerance breakdown may work in differently abnormal microenvironments (CHILOSI et al., 1986). In fact, we consider reduced levels of MHC class II expression as highly important for paraneoplastic autoimmunity as given in the pathogenetic model below.

\section{Abnormal Lymphoepithelial Interactions in Thymomas?}

While many features of lymphoepithelial interactions in the non-neoplastic mouse thymus have been defined at the molecular level (see above; SPITS et al., 1995), respective investigations are scarce in the normal human thymus (PATEL and HAYNES, 1994; RAMIRO et al., 1996) and lacking in thymomas. Therefore, abnormal lymphoepithelial interactions can be deduced only indirectly from abnormalities of the intratumorous thymocyte populations as defined by FACS analyses or functional assays. As we found recently, all developmental stages of thymocyte differentiation as shown in Figures 1 and 2 can be identified in thymomas by flow cytometry, suggesting that intratumorous thymopoiesis is generally maintained (NENNINGER et al., 1996). However, enormous quantitative differences with respect to the various subpopulations exist between thymomas and normal thymuses concerning early stages of thymocyte differentiation, positive selection and terminal maturation (TAKEUCHI et al., 1995). Each histological thymoma subtype exhibits typical abnormalities of the thymocyte subset composition as given for mixed and cortical thymomas in Figure 4 (NENNINGER et al., 1996). In contrast to mixed and cortical thymomas, immature $\mathrm{CD}^{-}$ $\mathrm{CD} 4^{+} \mathrm{CD} 8^{-}$and $\mathrm{CD} 4^{+} \mathrm{CD} 8^{+}$thymocytes are almost absent from medullary thumomas (not shown).

In our series of tumors there was a correlation between a decreased expression of MHC class II and inefficiency of positive selection and terminal matura- 
a Abnormal T-cell Development in Thymoma

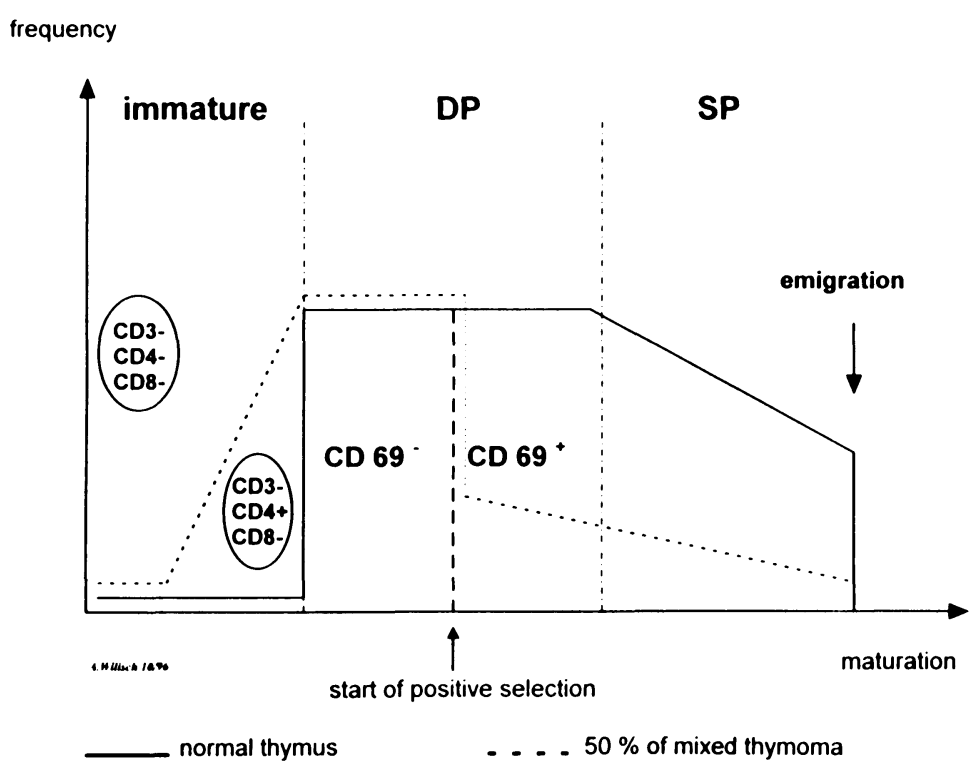

b

frequency

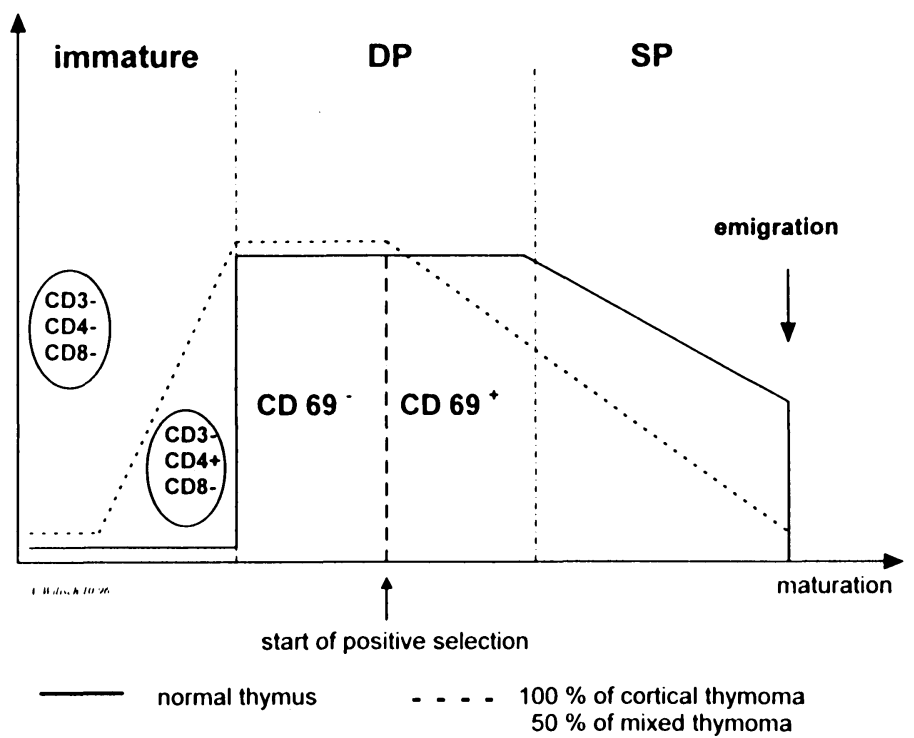

Fig. 4. Abnormal T cell development in thymomas of cortical and mixed type. 50\% of mixed thymomas (a) exhibit more severe defects in positive selection than all cortical and the other mixed type thymomas (b) (NENNINGER et al., 1996). Well differentiated thymic carcinomas (WDTC) (KIRCHNER et al., 1992) exhibit features similar to cortical thymomas. Characteristically there is an increase of immature $\mathrm{CD} 3{ }^{-} \mathrm{CD} 4^{+} \mathrm{CD} 8^{-}$thymocytes in these thymoma subtypes while mature thymocytes are decreased. In contrast, mature $T$ cells prevail in medullary thymomas by far (not shown). 


\section{T-Cell Selection in Normal Thymus}

a
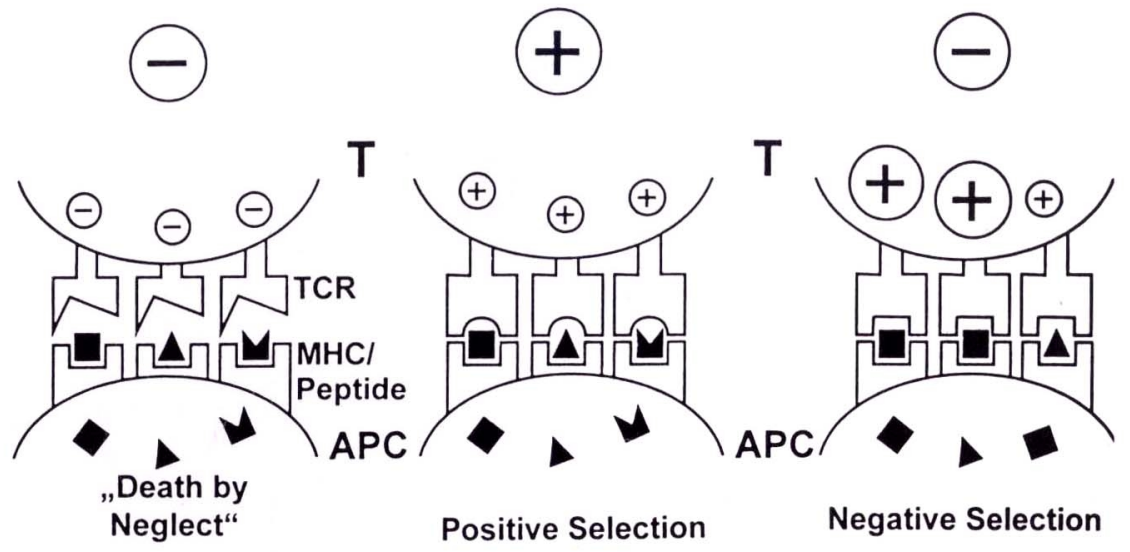

\section{T-Cell Selection in Thymoma}

b
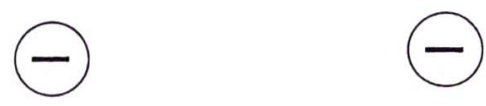

(1)

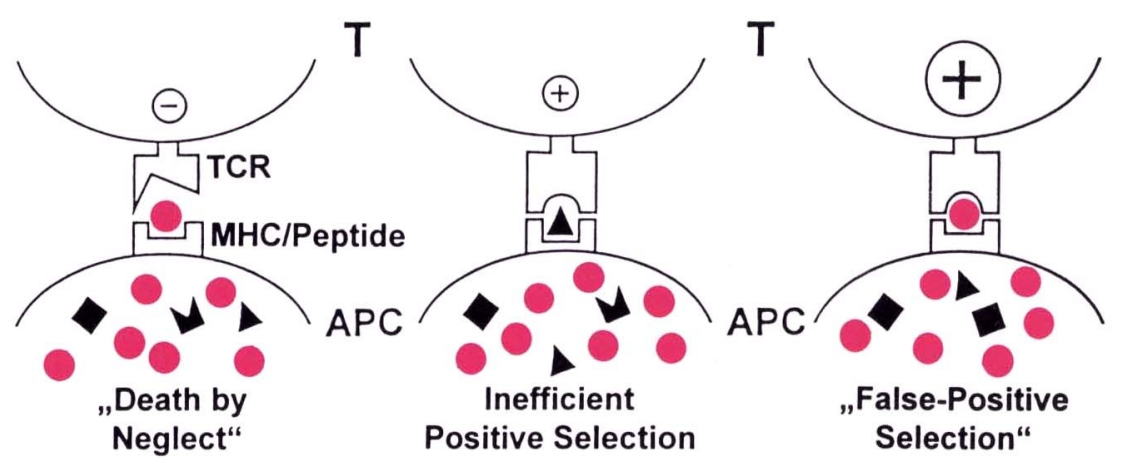

Fig. 5. Positive selection in the normal thymus (a) and in cortical type thymomas (b). Apoptosis can occur either by deletion because of too high an avidity between TCR and MHC/peptide complexes $(+++)$ or because of "death by neglect" with lack of survival signals (- - ). Positive selection occurs at intermediate levels of avidity $(+)$. In thymomas abnormally hyperexpressed endogenous neurofilaments (with AChR- and titin-like epitopes, Wilisch et al., 1996) in combination with decreased MHC class II levels should rescue neurofilamentreactive T cells (and crossreacting AChR-reacting T cells) from "death by neglect". In addition there should be inefficient positive selection of the usual $\mathrm{T}$ cell repertoire. Both predictions are supported by experimental evidence given in the text. 
Table 5. Morphological, functional, and epidemiological features different between thymitis-associated myasthenia gravis (MG) and thymoma-associated MG that might have a bearing for different mechanisms of MG pathogenesis

\begin{tabular}{lcc}
\hline Feature & $\begin{array}{c}\text { Thymitis-associated } \\
\text { myasthenia gravis }\end{array}$ & $\begin{array}{c}\text { Thymoma-associated } \\
\text { myasthenia gravis }\end{array}$ \\
\hline Myoid cells present & yes & no \\
AChR $^{1}$ present & yes & no \\
Number of IDC & high & low \\
Activated T cells & yes & no \\
Number of B cells & high & low/none \\
Autoantibody production & yes & no \\
HLA/gender association & yes & no \\
\hline
\end{tabular}

${ }^{1} \mathrm{AChR}$ : acetylcholine receptor, ${ }^{2} \mathrm{IDC}$ : interdigitating dendritic cells

\section{Pathogenesis of Paraneoplastic MG in Thymoma Patients \\ Thymoma Periphery}

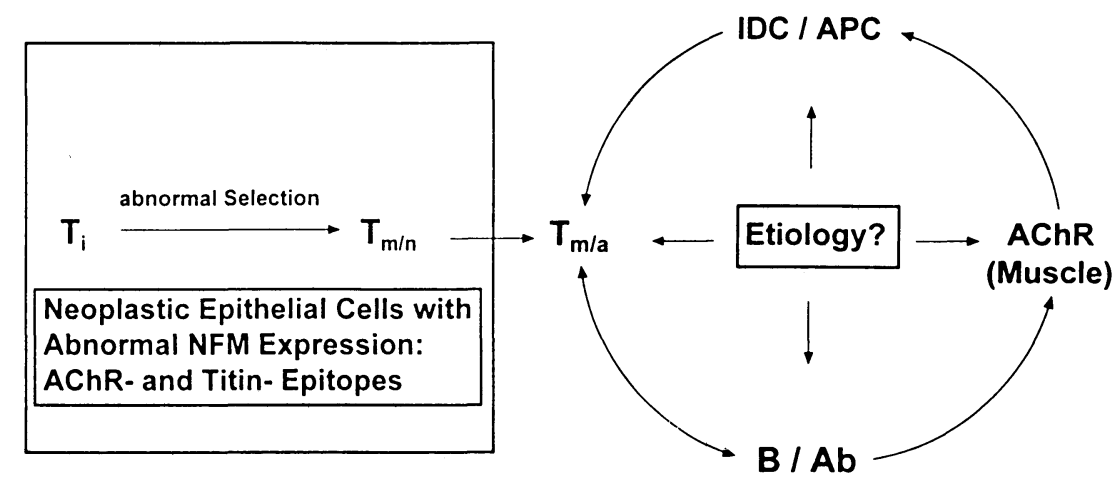

Fig. 6. A pathogenetic model of paraneoplastic $M G$ in thymoma patients. According to this model abnormal AChR- and titin-like epitopes provide the molecular basis for an autoantigen-specific abnormal positive selection that turns immature $\mathrm{T}$ cells (Ti) into mature and naive $\mathrm{T}$ cells $(\mathrm{Tm} / n)$. These $\mathrm{T}$ cells become activated $(\mathrm{Tm} /$ a) after export to the periphery, where they could stimulate $\mathrm{B}$ cells. The etiology triggering $\mathrm{T}$ cell activation is unknown. 
tion (NENNINGER et al., 1996) while this was not so obvious in another study (TAKEUCHI et al., 1995). In both studies cortical and mixed thymomas harbored considerably fewer mature $\mathrm{CD} 4^{+} \mathrm{T}$ cells than normal thymuses. Nevertheless, functional studies revealed a higher frequency of $\mathrm{T}$ cells with specificity for the autoantigen acetylcholine receptor (AChR) in most mixed and cortical thymomas (SOMMER et al., 1991; MARX et al., 1996a). Relative to the number of $\mathrm{CD}^{+}$ mature $\mathrm{T}$ cells, AChR-reactive thymocytes were increased up to 25 fold as compared to normal controls (Schultz, 1997). No correlation between the increased number of potentially autoaggressive $T$ cells and the occurrence of myasthenia gravis was found (SCHUlTZ, 1997). In summary, these findings suggest an abnormal thymocyte/stroma interation in thymomas.

\section{Thymoma-Associated (Paraneoplastic) Myasthenia Gravis by Abnormal Lymphoepithelial Interactions?}

Myasthenia gravis (MG) comprises a group of autoimmune diseases characterized by muscle weakness due to autoantibodies against the acetylcholine receptor (AChR) (reviewed by MARX et al., 1996a). MG is heterogeneous with respect to clinical, immunological and pathological findings (VINCENT, 1994). Autoantibody production in MG is $\mathrm{T}$ cell dependent (HOHLFELD et al., 1984; MELms et al., 1992). Remarkably, pathology of thymus is an almost constant finding. Thymitis, thymoma or thymic atrophy occur in 70,20 , and $10 \%$ of MG patients, respectively (MÜLLER-HERMELINK et al., 1996). While the pathogenesis of MG in thymic atrophy is obscure, MG in thymitis is considered the consequence of a $\mathrm{T}$ cell dependent humoral immune reaction that takes place completly inside the thymus and probably starts there (WEKERLE and KETELSEN, 1977; MeINL et al., 1991). The intrathymic immune reaction in thymitis encompasses the AChR (on myoid cells) as the (triggerring) autoantigen, IDC as antigen presenting cells, AChR-specific and activated $\mathrm{CD} 4^{+} \mathrm{T}$ cells and autoantibody secreting $\mathrm{B}$ cells. Thymectomy improves thymitis-associated MG by eliminating the main source of autoantibody production (reviewed by MARX et al., 1996a, 1997). This is not the case with paraneoplastic MG that differs from thymitis-associated $\mathrm{MG}$ in almost any respect (Table 5).

Paraneoplastic MG is also distinguished by the specific occurrence of autoantibodies against the muscle proteins titin and ryanodine receptor (AARLI et al., 1990; MYGLAND et al., 1995) and against neuronal proteins (MARX et al., 1992) in addition to
anti-AChR autoantibodies. With respect to the autoantigens of paraneoplastic MG it is a shared principle that $\mathrm{AChR}$, titin and ryanodine receptors themselves are not expressed in thymomas but that crossreacting epitopes are (KIRCHNER et al., 1988; MARX et al., 1990; MYGLAND et al., 1995). Recently, we found that the AChR- and titin-like epitopes expressed in thymomas are constituents of neurofilaments that are abnormally expressed in thymomas (MARX et al., 1996b; WILISCH et al., 1996).

In our opinion the following findings await explanation by an appropriate pathogenetic model: 1) Paraneoplastic MG occurs only in organotypic thymic epithelial tumors that contain immature $\mathrm{CD}^{+}$thymocytes (MÜlLER-HERMELINK et al., 1996). 2) Thymomas with cortical differentiation and probably mixed thymomas (unpublished) abnormally express neurofilaments (with AChR- and titin-like epitopes) and ryanodine receptor-like epitopes and this abnormal expression is associated with autoimmunity against these autoantigens. 3) AChR- and neurofilament-reactive $T$ cells occur in increased numbers inside mixed and cortical thymomas (SOMMER et al., 1990; MARX et al., 1996a) and these T cells are not activated in situ (SCHULTZ, 1997). 4) B cells producing autoantibodies are absent from thymomas (FUjII et al., 1984).

Considering evidence from mice that endogenous peptides are involved in positive selection (reviewed by ASHTON-RICKARDT and TONEGAWA, 1994) and that abnormal peptide loading on MHC class II molecules alters T cell selection (MARTIN et al., 1996) we hypothesize that abnormally expressed neurofilaments in cortcal and mixed thymomas might cause "falsepositive selection" of immature T cells by rescuing them from "death by neglect" (MARX et al., 1992). The characteristic abnormalities of the neoplastic thymic microenvironment-abnormal intraepithelial expression of neurofilaments with $\mathrm{AChR}$ and titin epitopes in a cortical microenvironment combined with decreased levels of epithelial MHC class II (Fig. 5)-would explain both the overall inefficiency of intratumorous positive $T$ cell selection (TAKEUCHI et al., 1995; NENNINGER et al., 1996) and the increased number of AChR and titin-reactive T cells (SOMMER et al., 1990; MARX et al., 1996a). Since the autoantigen-reactive $\mathrm{T}$ cells are not activated inside thymomas (SCHULTZ, 1997) we assume that they become activated after export to the periphery and could stimulate the production of autoantibodies there (Fig. 6). The etiologic processes activating $T$ cells after their export to the periphery have yet to be elucidated (VINCENT, 1994). Likewise, the pathogenesis of $\mathrm{MG}$ in medullary thymomas awaits further analyses. 


\section{REFERENCES}

Aarli, J. A., K. Stefansson, L. S. Marton and R. L. Wollmann: Patients with myasthenia gravis and thymoma have in their sera IgG autoantibodies against titin. Clin. Exp. Immunol. 82: 284-288 (1990).

Adachi, M., S. Suematsu, T. Suda, D. Watanabe, H. Fukuyama, J. Ogasawara, T. Tanaka, N. Yoshida and S. Nagata: Enhanced and accelerated lymphoproliferation in Fas-null mice. Proc. Nat. Acad. Sci. U. S.A. 93: 2131-2136 (1996).

Alberola Ila, J., K. A. Forbush, R. Seger, E. G. Krebs and R. M. Perlmutter: Selective requirement for MAP kinase activation in thymocyte differentitation. Nature 373: 620-623 (1995).

Allen, P. M.: Peptides in positive and negative selection: a delicate balance [comment]. Cell 76: 593-596 (1994).

Amakawa, R., A. Hakem, T. M. Kundig, T. Matsuyama, J. J. Simard, E. Timms, A. Wakeham, H. W. MitTruecker, H. Griesser, H. TAKimoto, R. Schmits, A. Shahinian, P. Ohashi, J. M. Penninger and T. W. MAK: Impaired negative selection of $\mathrm{T}$ cells in Hodgkin's disease antigen CD30-deficient mice. Cell 84: 551562 (1996).

Anderson, G., E. J. Jenkinson, N. C. Moore and J. J. OWEN: MHC class II-positive epithelium and mesenchyme cells are both required for T-cell development in the thymus. Nature 362: 70-73 (1993).

Anderson, G., J. J. Owen, N. C. Moore and E. J. Jenkinson: Thymic epithelial cells provide unique signals for positive selection of $\mathrm{CD} 4+\mathrm{CD} 8+$ thymocytes in vitro. J. Exp. Med. 179: 2027-2031 (1994).

Anderson, K. L., G. Anderson, R. H. Michell, E. J. JENKINSON and J. J. OWEN: Intracellular signaling pathways involved in the induction of apoptosis in immature thymic $\mathrm{T}$ lymphocytes. J. Immunol. 156: 4083-4091 (1996).

Ardavin, C., L. Wu, C. L. Li and K. Shortman: Thymic dendritic cells and $\mathrm{T}$ cells develop simultaneously in the thymus from a common precursor population. Nature 362: 761-763 (1993).

Arpaia, E., M. Shahar, H. Dadi, A. Cohen and C. M. RoIfMAN: Defective $\mathrm{T}$ cell receptor signaling and $\mathrm{CD} 8+$ thymic selection in humans lacking zap-70 kinase. Cell 76: 947-958 (1994).

ashton Rickardt, P. G. and S. Tonegawa: A differential-avidity model for T-cell selection. Immunol. Today 15: 362-366 (1994).

Aurrand-Lions, M., F. Galland, H. Bazin, V. M. ZakharYeV, B. A. ImhoF and P. Naquet: Vanin-1, a novel GPI-linked perivascular molecule involved thymus homing. Immunity 5: 391-405 (1996).

Bacchetta, R., B. A. Vandekerchhove, J. L. Touraine, M. Bigler, S. Martino, L. Gebuhrer, J. E. DE Vries, H. SpITs and M. G. Roncarolo: Chimerism and tolerance to host and donor in severe combined immunodeficiencies transplanted with fetal liver stem cells. J. Clin. Invest. 91: 1067-1078 (1993).
Bacchetta, R., M. Bigler, J. L. Touraine, R. Parkman, P. A. Tovo, J. Abrams, R. de WaAl Malefyt, J. E. de VRIES and M. G. Roncarolo: High levels of interleukin 10 production in vivo are associated with tolerance in SCID patients transplanted with HLA mismatched hematopoietic stem cells. J. Exp. Med. 179: 493-502 (1994).

Barcena, A., A. H. Galy, J. Punnonen, M. O. Muench, D. Schols, M. G. Roncarolo, J. E. DE VRIES and H. SPITS: Lymphoid and myeloid differentiation of fetal liver CD34 + lineage-cells in human thymic organ culture. J. Exp. Med. 180: 123-132 (1994).

Berrih, S., W. Savino and S. Cohen: Extracellular matrix of the human thymus: immunofluorescence studies on frozen sections and cultured epithelial cells. J. Histochem. Cytochem. 33: 655-664 (1985).

Boehm, T., M. Nehls and B. KYeWsKI: Transcription factors that control development of the thymic microenvironment. Immunol. Today 16: 555-556 (1995).

Bofill, M., G. Janossy, N. Willcox, M. Chilosi, L. K. Trejdosiewicz and J. Newsom Davis: Microenvironments in the normal thymus and the thymus in myasthenia gravis. Amer. J. Pathol. 119: 462-473 (1985).

Bories, J. C., D. M. Willerford, D. GRevin, L. DAVIDson, A. Camus, P. Martin, D. Stehelin and F. W. ALT: Increased T-cell apoptosis and terminal B-cell differentiation induced by inactivation of the Ets-1 proto-oncogene. Nature 377: 635-638 (1995).

Bornemann, A. and T. Kirchner: An immuno-electronmicroscopic study of human thymic B cells. Cell. Tiss. Res. 284: 481-487 (1996).

BOYD, R. L., C. L. TuCEK, D. I. GOdFReY, D. J. IZON, T. J. Wilson, N. J. Davidson, A. G. Bean, H. M. Ladyman, M. A. Ritter and P. Hugo: The thymic microenvironment [see comments]. Immunol. Today 14: 445-459 (1993)

Burkly, L., C. Hession, L. Ogata, C. Reilly, L. A. Marconi, D. Olson, R. Tizard, R. Cate and D. Lo: Expression of relB is required for the development of thymic medulla and dendritic cells. Nature 373: 531-536 (1995)

Calnan, B. J., S. Szychowski, F. K. Chan, D. Cado and A. Winoto: A role for the orphan steroid receptor Nur77 in apoptosis accompanying antigen-induced negative selection. Immunity 3: 273-282 (1995).

Chan, J. K., W. Y. Tsang, S. Seneviratne and M. Y. PAU: The MIC2 antibody 013. Practical application for the study of thymic epithelial tumors. Amer. J. Surg. Pathol. 19: 1115-1123 (1995).

Chan, W. C., G. S. ZaAtari, S. Tabei, M. BibB and R. K. BRYNES: Thymoma: an immunohistochemical study. Amer. J. Clin. Pathol. 82: 160-166 (1984).

Chilosi, M., A. M. Iannucci, G. Pizzolo, F. MeneStrina, L. Fiore Donati and G. JANossy: Immunohistochemical analysis of thymoma. Evidence for medullary origin of epithelial cells. Amer. J. Surg. Pathol. 8: 309-318 (1984).

Chilosi, M., A. Iannucci, L. Fiore Donati, G. Tridente, M. Pampanin, G. Pizzolo, M. Ritter, M. 
BofILL and G. JANossY: Myasthenia gravis: Immunohistological heterogeneity in microenvironmental organization of hyperplastic and neoplastic thymuses suggesting different mechanisms of tolerance breakdown. J. Neuroimmunol. 11: 191-204 (1986).

Clark, E. A. and J. A. Ledbetter: How B and T cells talk to each other. Nature 367: 425-428 (1994).

Close, P. M., T. Kirchner, C. J. UYs and H. K. MÜLLER-HERMELINK: Reproducibility of a histogenetic classification of thymic epithelial tumours. Histopathology 26: 339-343 (1995).

Dalloul, A. H., M. Arock, C. Fourcade, A. Hatzfeld, J. M. Bertho, P. Debre and M. D. Mossalayi: Human thymic epithelial cells produce interleukin-3. Blood 77: 69-74 (1991).

Dardenne, M. and W. Savino: Control of thymus physiology by peptidic hormones and neuropeptides. Immunol. Today 15: 518-523 (1994).

de MaAgd, R. A., W. A. Mackenzie, H. J. Schuurman, M, A. Ritter, K. M. Price, R. Broekhuizen and L. KATER: The human thymus microenvironment: Heterogeneity detected by monoclonal anti-epithelial cell antibodies. Immunology 54: 745-754 (1985).

Del Porto, P., L. Bruno, M. G. Mattei, H. von BoehMER and C. SAINT RUF: Cloning and comparative analysis of the human pre-T-cell receptor alpha-chain gene. Proc. Nat. Acad. Sci. U.S.A. 92: 12105-12109 (1995).

Drenckhahn, D., B. von Gaudecker, H. K. MüllerHermelink, K. Unsicker and U. Groschel Stewart : Myosin and actin containing cells in the human postnatal thymus. Ultrastructural and immunohistochemical findings in normal thymus and in myasthenia gravis. Virchows Arch. B. Cell. Pathol. Incl. Mol. Pathol. 32: 33-45 (1979).

Dunn Walters, D. K., C. J. Howe, P. G. IsaAcson and J. SPENCER: Location and sequence of rearranged immunoglobulin genes in human thymus. Eur. J. Immunol. 25: 513-519 (1995).

Elder, M. E., D. Lin, J. Clever, A. C. Chan, T. J. Hope, A. Weiss and T. G. Parslow: Human severe combined immunodeficiency due to a defect in ZAP-70, a T cell tyrosine kinase. Science 264: 1596-1599 (1994).

Fend, F., D. Nachbaur, F. Oberwasserlechner, A. Kreczy, H. Huber and H. K. Müller-HermelinK: Phenotype and topography of human thymic B cells. An immunohistologic study. Virchows Arch. B Cell. Pathol. Incl. Mol. Pathol. 60: 381-388 (1991).

Fend, F., T. Kirchner, A. Marx and H. K. MüllerHermelink: B-cells in thymic epithelial tumours. An immunohistochemical analysis of intra- and extraepithelial B-cell compartments. Virchows Arch. B. Cell. Pathol. Incl. Mol. Pathol. 63: 241-247 (1993).

Fernandez, E., A. Vicente, A. Zapata, B. Brera, J. J. Lozano, C. Martinez and M. L. Toribio: Establishment and characterization of cloned human thymic epithelial cell lines. Analysis of adhesion molecule expression and cytokine production. Blood 83: 32453254 (1994).

Fine, J. S. and A. M. KRUisbeek: The role of LFA-1/
ICAM-1 interactions during murine $\mathrm{T}$ lymphocyte development. J. Immunol. 147: 2852-2859 (1991).

Fischer, K. D., A. Zmuldzinas, S. Gardner, M. BARbacid, A. Bernstein and C. Guidos: Defective T-cell receptor signalling and positive selection of Vav-deficient CD4+ CD8 + thymocytes. Nature 374: 474-477 (1995).

Foy, T. M., D. M. Page, T. J. W ALDSChmidt, A. Schoneveld, J. D. Laman, S. R. Masters, L. Tygrett, J. A. Ledbetter, A. Aruffo, E. Claassen, J. C. Xu, R. A. Flavell, S. Oehen, S. M. Hedrick and R. J. Noelle: An essential role for gp39, the ligand for CD40, in thymic selection. The Rockefeller University Press 182: 1377-1388 (1995).

FuJi, Y., Y. Monden, K. Nakahara, J. Hashimoto and Y. KaWAShima: Antibody to acetylcholine receptor in myasthenia gravis: production by lymphocytes from thymus or thymoma. Neurology 34: 1182-1186 (1984).

GALY, A. H. and H. SPITS: IL-1, IL-4, and IFN-gamma differentially regulate cytokine production and cell surface molecule expression in cultured human thymic epithelial cells. J. Immunol. 147: 3823-3830 (1991).

- CD40 is functionally expressed on human thymic epithelial cells. J. Immunol. 149: 775-782 (1992).

Galy, A. H., R. De W Aal Malefyt, A. Barcena, S. M. PETERson and H. SPITs: Untransfected and SV 40-transfected fetal and postnatal human thymic stromal cells. Analysis of phenotype, cytokine gene expression and cytokine production. Thymus 22: 13-33 (1993).

Geuder, K. I., A. Marx, V. Witzemann, B. Schalke, K. TOYKA, T. Kirchner and H. K. MÜLler-HermelinK: Pathogenetic significance of fetal-type acetylcholine receptors on thymic myoid cells in myasthenia gravis Devel. Immunol. 2: 69-75 (1992).

Gilhus, N. E., J. A. Aarli, B. Christensson and R. MATRE: Rabbit antiserum to a citric acid extract of human skeletal muscle staining thymomas from myasthenia gravis patients. J. Neuroimmunol. 7: 55-64 (1984).

Gilhus, N. E., N. Willcox, G. Harcourt, N. Nagve KaR, D. Beeson, A. Vincent and J. Newsom-Davis: Antigen presentation by thymoma epithelial cells from myasthenia gravis patients to potentially pathogenic $\mathrm{T}$ cells. J. Neuroimmunol. 56: 65-76 (1995).

Giunta, M., A. Favre, D. Ramarli, C. E. Grossi and G. CoRTE: A novel integrin involved in thymocyte-thymic epithelial cell interactions. J. Exp. Med. 173: 1537-1548 (1991).

Grabstein, K. H., T. J. W aldscmidt, F. D. Finkelman, B. W. Hess, A. R. Alpert, N. E. Boiani, A. E. Namen and P. J. Morrissey: Inhibition of murine $B$ and $T$ lymphopoiesis in vivo by an anti-interleukin 7 monoclonal antibody. J. Exp. Med. 178: 257-264 (1993).

HaYnes, B. F.: The human thymic microenvironment. Adv. Immunol. 36: 87-142 (1984).

Haynes, B. F. and C. S. Heinly: Early human T cell development: analysis of the human thymus at the time of initial entry of hematopoietic stem cells into the fetal thymic microenvironment. J. Exp. Med. 181: 1445-1458 
(1995).

Haynes, B. F., S. M. Denning, P. T. LE and K. H. SINGER: Human intrathymic $\mathrm{T}$ cell differentiation. Semin. Immunol. 2: 67-77 (1990).

Hogquist, K. A., M. A. Gavin and M. J. Bevan: Positive selection of $\mathrm{CD} 8+\mathrm{T}$ cells induced by major histocompatibility complex binding peptides in fetal thymic organ culture. J. Exp. Med. 177: 1469-1473 (1993).

Hohlfeld, R., K. V. Toyka, K. Heininger, H. Groosse WILDE and I. KAliEs: Autoimmune human $T$ lymphocytes specific for acetylcholine receptor. Nature 310: 244-246 (1984).

Hozumi, K., M. Kondo, H. NozAKI, A. KoborI, T. NishimuRA, S. NichikaWA, K. Sugamura and S. HabU: Implication of the common gamma chain of the IL-7 receptor in intrathymic development of pro-T cells. Int. Immunol. 6: 1451-1454 (1994).

Ichikawa, T., O. Taguchi, T. Takahashi, H. Ikeda, M. Takeuchi, T. Tanaka, M. Usui and Y. Nishizuka: Spontaneous development of autoimmune uveoretinitis in nude mice following reconstitution with embryonic rat thymus. Clin. Exp. Immunol. 86: 112-117 (1991).

Isaacson, P. G., A. J. Norton and B. J. Addis: The human thymus contains a novel population of $\mathrm{B}$ lymphocytes. Lancet 2: 1488-1491 (1987).

Izon, D. J. and R. L. BoyD: The cytoarchitecture of the human thymus detected by monoclonal antibodies. Hum. Immunol. 27: 16-32 (1990).

JoRDAn, R. K. and J. H. Robinson: T-lymphocyte differentiation. In: (ed. by) M. D. KENDALL: The thymus gland. Academic Press, London, 1981 (p. 151-177).

Kaiserling, E., H. Stein and H. K. Müller-HerMELINK: Interdigitating reticulum cells in the human thymus. Cell. Tiss. Res. 155: 47-55 (1974).

KaO, I. and D. B. Drachman: Thymic muscle cells bear acetylcholine receptors: possible relation to myasthenia gravis. Science 195: 74-75 (1977).

Kasai, M., K. Hirokawa, K. KaJino, K. Ogasawara, M. Tatsumi, E. Hermel, J. J. Monaco and T. Mizuochi: Difference in antigen presentation pathways between cortical and medullary thymic epithelial cells. Eur. J. Immunol. 26: 2101-2107 (1996).

Killeen, N., S. G. StuarT and D. R. Littman: Development and function of $\mathrm{T}$ cells in mice with a disrupted CD2 gene. EMBO. J. 11: 4329-4336 (1992).

Kimoto, H., T. Shirasawa, M. TANigUCHI and T. TAKemori: $\mathrm{B}$ cell precursors are present in the thymus during early development. Eur. J. Immunol. 19: 97-104 (1989).

Kirchner, T., B. Schalke, A. Melms, T. von Kugelgen and H. K. MÜLlER-HERMELINK: Immunohistological patterns of non-neoplastic changes in the thymus in myasthenia gravis. Virchows. Arch. B. Cell. Pathol. Incl. Mol. Pathol. 52: 237-257 (1986).

Kirchner, T., S. Tzartos, F. Hoppe, B. Schalke, H. Wekerle and H. K. Müller-Hermelink: Pathogenesis of myasthenia gravis. Acetylcholine receptor-related antigenic determinants in tumor-free thymuses and thymic epithelial tumors. Amer. J. Pathol. 130: 268-280 (1988).
Kirchner, T., B. Schalke, J. Buchwald, M. RitTer, A. MARX and H. K. MüLler-Hermelink: Well-differentiated thymic carcinoma. An organotypical low-grade carcinoma with relationship to cortical thymoma. Amer. J. Surg. Pathol. 16: 1153-1169 (1992).

Kishihara, K., J. Penninger, V. A. Wallace, T. M. Kundig, K. Kawai, A. Wakeham, E. Timms, K. Pfef FER, P. S. OHAshi, M. L. Thomas, et al.: Normal B lymphocyte development but impaired $\mathrm{T}$ cell maturation in CD45-exon6 protein tyrosine phosphatase-deficient mice. Cell 74: 143-156 (1993).

Kishimoto, H., Z. Cai, A. Brunmark, M. R. Jackson, P. A. Peterson and J. Sprent : Differing roles for B7 and intercellular adhesion molecule-1 in negative selection of thymocytes [see comments]. J. Exp. Med. 184: 531537 (1996).

Kisielow, P. and H. von Boehmer: Development and selection of T cells: facts and puzzles. Adv. Immunol. 58: 87-209 (1995).

Kraus, V. B., E. A. Harden, B. Wittels, J. O. Moore and B. F. HAYNES: Demonstration of phenotypic abnormalities of thymic epithelium in thymoma including two cases with abundant Langerhans cells. Amer. J. Pathol. 132: 552-562 (1988).

Lanier, L. L., J. P. Allison and J. H. Phillips: Correlation of cell surface antigen expression on human thymocytes by multi-color flow cytometric analysis: implications for differentiation. J. Immunol. 137: 25012507 (1986).

Lannes Vieira, J., M. Dardenne and W. Savino: Extracellular matrix components of the mouse thymus microenvironment: ontogenetic studies and modulation by glucocorticoid hormones. J. Histochem. Cytochem. 39: 1539-1546 (1991).

Lauriola, L., F. Michetti, V. M. Stolfi, G. Tallini and D. Cocchia: Detection by S-100 immunolabelling of interdigitating reticulum cells in human thymomas. Virchows Arch. B. Cell. Pathol. Incl. Mol. Pathol. 45: 187-195 (1984).

Lerner, A., L. K. Clayton, E. Mizoguchi, Y. Ghendler, W. van EWIJK, S. KoYASU, A. K. BHAN and E. REINHERZ: Cross-linking of $\mathrm{T}$-cell receptors on double-positive thymocytes induces a cytokine-mediated stromal activation process linked to cell death. EMBO J. 15: 58765887 (1996).

Levelt, C. N., P. Mombaerts, A. Iglesias, S. Tonegawa and K. Eichmann: Restoration of early thymocyte differentiation in $\mathrm{T}$-cell receptor beta-chain-deficient mutant mice by transmembrane signaling through CD3 epsilon. Proc. Nat. Acad. Sci. U.S.A. 90: 11401-11405 (1993).

LuCAS, B. and R. N. Germain: Unexpectedly complex regulation of $\mathrm{CD} 4 / \mathrm{CD} 8$ coreceptor expression supports a revised model for $\mathrm{CD} 4+/ \mathrm{CD} 8+$ thymocyted differentiation. Immunity 5: 461-477 (1996).

Ma, A., J. C. Pena, B. Chang, E. Margosian, L. Davidson, F. W. Alt and C. B. Thompson: Bclx regulates the survival of double-positive thymocytes. Proc. Nat. Acad. Sci. U.S.A. 92: 4763-4767 (1995). 
Maggiano, N., M. Piantelli, R. Ricci, L. M. Larocca, A. CAPelli and F. O. RANELletti: Detection of growth hormone-producing cells in human thymus by immunohistochemistry and non-radioactive in situ hybridization. J. Histochem. Cytochem. 42: 1349-1354 (1994).

MARINo, M. and H. K. MÜLler-Hermelink: Thymoma and thymic carcinoma. Relation of thymoma epithelial cells to the cortical and medullary differentiation of thymus. Virchows Arch. A. Pathol. Anat. Histopathol. 407: 119-149 (1985).

Martin, W. D., G. G. Hicks, S. K. Mendiratta, H. I. LeVa, H. E. Ruley and L. VaN KaER: H2-M mutant mice are defective in the peptide loading of class II molecules, antigen presentation, and $\mathrm{T}$ cell repertoire selection. Cell 84: 543-550 (1996).

Marx, A., R. O'Connor, K. I. Geuder, F. Hoppe, B. Schalke, S. Tzartos, I. Kalies, T. Kirchner and H. K. MüLleR-Hermelink: Characterization of a protein with an acetylcholine receptor epitope from myasthenia gravis-associated thymomas [see comments]. Lab. Invest. 62: 279-286 (1990).

MarX, A., T. Kirchner, A. Greiner, H. K. MüllerHermelink, B. Schalke and M. Osborn: Neurofilament epitopes in thymoma and antiaxonal autoantibodies in myasthenia gravis. Lancet 339: 707-708 (1992).

Marx, A., D. Schömig, A. Schultz, S. Gattenlöhner, A. Jung, T. Kirchner, A. Melms and H. K. MüllerHermelink: Distribution of molecules mediating thymocyte-stroma-interactions in human thymus, thymitis and thymic epithelial tumors. Thymus 23: 83-93 (1994).

Marx, A., A. Schultz, A. Wilisch, R. Nenninger and H. K. Müller-Hermelink: Myasthenia gravis. Verh. Deut. Ges. Pathol. 80: 116-126 (1996a).

Marx, A., A. Wilisch, A. Schultz, A. Greiner, B. Magi, V. Pallini, B. Schalke, K. Toyka, W. Nix, T. Kirchner and H. K. Müller-Hermelink: Expression of neurofilaments and of a titin epitope in thymic epithelial tumors. Implications for the pathogenesis of myasthenia gravis. Amer. J. Pathol. 148: 1839-1850 (1996b).

Marx, A., A. Wilisch, A. Schultz, S. Gattenlöhner, R. Nenninger and H. K. MÜller-Hermelink: Pathogenesis of myasthenia gravis. Virchows Arch. (1997, in press).

MatsuZaki, Y., J. Gyotoku, M. Ogawa, S. Nishikawa, Y. Katsura, G. GaChelin and H. Nakauchi: Characterization of c-kit positive intrathymic stem cells that are restricted to lymphoid differentiation. J. Exp. Med. 178: 1283-1292 (1993).

MaZda, O., Y. Watanabe, J. GyotokU and Y. Katsura: Requirement of dendritic cells and B cells in the clonal deletion of Mls-reactive T cells in the thymus. J. Exp. Med. 173: 539-547 (1991).

Meilin, A., J. Shoham and Y. Sharabi: Analysis of thymic stromal cell subpopulations grown in vitro on extracellular matrix in defined medium. IV. Cytokines secreted by human thymic epithelial cells culture and their activities on murine thymocytes and bone marrow cells. Immunology 77: 208-213 (1992).

Meinl, E., W. E. Klinekert and H. Wekerle: The thymus in myasthenia gravis. Changes typical for the human disease are absent in experimental autoimmune myasthenia gravis of the Lewis rat. Amer. J. Pathol. 139: 995-1008 (1991).

Melms, A., G. Malcherek, U. Gern, H. Wietholter, C. A. Muller, R. Schoepfer and J. Lindstrom: T cells from normal and myasthenic individuals recognize the human acetylcholine receptor: heterogeneity of antigenic sites on the alpha-subunit. Ann. Neurol. 31: 311-318 (1992).

MokhtaR, N., S. M. Hsu, R. P. LAD, B. F. HAYnes and E. S. JAFFE: Thymomal: lymphoid and epithelial components mirror the phenotype of normal thymus. Hum. Pathol. 15: 378-384 (1984).

Molina, T. J., K. Kishihara, D. P. Siderovski, W. van EwiJk, A. Narendran, E. Timms, A. Wakeham, C. J. Paige, K. U. Hartmann, A. Veillette, et al.: Profound block in thymocyte development in mice lacking p561ck [see comments]. Nature 357: 161-164 (1992).

MÜller-HermelinK, H. K.: The human thymus histophysiology and pathology. Springer Verlag, BerlinHeidelberg-New York-Tokyo, 1986.

Müller-Hermelink, H. K., A. MARX and T. KirChNer: Thymus and mediastinum. In: (ed. by) I. DAmJANOV and J. Linder: Anderson's pathology. Patterson, A. S., St. Lous, Missouri, 1996 (p. 1218-1255).

Mygland, A., G. Kuwajima, K. Mikoshiba, O. B. Tysnes, J. A. Aarli and N. E. Gilhus: Thymomas express epitopes shared by the ryanodine receptor. J. Neuroimmunol. 62: 79-83 (1995).

Negishi, I., N. Motoyama, K. Nakayama, S. SenJu, S. Hatakeyama, Q. Zhang, A. C. Chan and D. Y. Loh: Essential role for ZAP-70 in both positive and negative selection of thymocytes. Nature 376: 435-438 (1995).

Nehls, M., B. Kyewski, M. Messerle, R. W AldschutZ, K. Schuddekopf, A. J. Smith and T. Boенм: Two genetically separable steps in the differentiation of thymic epithelium. Science 272: 886-889 (1996).

Nenninger, R., A. Schultz, H. K. Müller-Hermelink, and A. MARX: Abnormal T cell maturation in myasthenia gravis associated thymomas. Verh. Deut. Ges. Pathol. 80: 256-260 (1996).

Nezelof, C.: Thymic pathology in primary and secondary immunodeficiencies. Histopathology 21: 499-511 (1992).

Nossal, G. J.: Negative selection of lymphocytes. Cell 76 : 229-239 (1994).

Onodera, J., S. Nakamura, I. Nagano, M. Tobita, M. Yoshioka, A. TAKeda and M. OouCHI: Upregulation of Bcl-2 protein in the myasthenic thymus. Ann. Neurol. 39: 521-528 (1996).

Owen, M. J. and A. R. Venkitaraman: Signalling in lymphocyte development. Current Opinion Immunol. 8: 191-198 (1996).

Patel, D. D. and B. F. Haynes: Stage-specific adhesion molecules in human intrathymic T-cell development. Res. Immunol. 145: 144-146 (1994).

Patal, D. D., L. P. Hale, L. P. Whichard, G. Radcliff, C. R. MaCkAY and B. F. Haynes: Expression of CD44 
molecules and CD44 ligands during human thymic fetal development: expression of CD44 isoforms is developmentally regulated. Int. Immunol. 7: 277-286 (1995).

Penninger, J. and G. Wick: Thymic nurse cell lymphocytes react against self major histocompatibility complex. Eur. J. Immunol. 22: 79-83 (1992).

Quintanilla Martinez, L., E. W. Wilkins, Jr., J. A. FerRY and N. L. HARRIS: Thymoma-morphologic subclassification correlates with invasiveness and immunohistologic features: a study of 122 cases. Hum. Pathol. 24: 958-969 (1993).

Ramiro, A. R., C. Trigueros, C. Marquez, J. L. SAN Millan and M. L. Toribio: Regulation of pre-T cell receptor ( $\mathrm{pT}$ alpha-TCR beta) gene expression during human thymic development. J. Exp. Med. 184: 519-530 (1996).

Res, P., E. Martinez, Caceres, A. Cristina Jaleco, F. StaAl, E. Noteboom, K. WeiJer and H. SPITS: CD34+ CD38dim cells in the human thymus can differentiate into $\mathrm{T}$, natural killer, and dendritic cells but are distinct from pluripotent stem cells. Blood 87: 5196-5206 (1996).

RitTer, M. A. and R. L. Boyd: Development in the thymus: it takes two to tango [see comments]. Immunol. Today 14: 462-469 (1993).

RITTER, M. A. and N. I. N. CRISPE: The thymus. IRL Press, Oxford 1992.

RitTer, M. A., C. A. Sauvage and S. F. Cotmore: The human thymus microenvironment: in vivo identification of thymic nurse cells and other antigenically-distinct subpopulations of epithelial cells. Immunology 44: 439446 (1981).

Ropke, C. and J. Elbroend: Human thymic epithelial cells in serum-free culture: nature and effects on thymocyte cell lines. Devel. Immunol. 2: 111-121 (1992).

RosaI, J.: Mediastinum. In: (ed. by) J. RosaI: Ackerman's surgical pathology. Patterson, A. S., St. Louis, 1996 (p. 435-491).

Rosai, J. and G. D. Levine: Atlas of tumor pathology: Tumors of the thymus. Armed Forces Institute of Pathology, Washington, 1976.

Ruco, L. P., P. Paradiso, M. Pittiglio, M. G. Diodoro, A. J. Gearing, F. Mainiero, A. Gismondi, A. Santoni and C. D. BARoni: Tissue distribution of very late activation antigens- $1 / 6$ and very late activation antigen ligands in the normal thymus and in thymoma. Amer. J. Pathol. 142: 765-772 (1993).

Saint-Ruf, C., K. Ungewiss, M. Groettrup, L. Bruno, H. J. Fehling and H. von Boehmer: Analysis and expression of a cloned pre-T cell receptor gene. Science 266: 1208-1212 (1994).

Sanchez, M. J., M. O. Muench, M. G. Roncarolo, L. L. LANiER and J. H. Phillips: Identification of a common $\mathrm{T} /$ natural killer cell progenitor in human fetal thymus. J. Exp. Med. 180: 569-576 (1994).

Savino, W., D. M. Villa Verde and J. Lannes Vieira: Extracellular matrix proteins in intrathymic T-cell migration and differentiation? Immunol. Today 14: 158161 (1993).

SchlueP, M., N. Willcox, M. A. RitTer, J. Newsom
Davis, M. LARChe and A. N. Brown: Myasthenia gravis thymus: clinical, histological and culture correlations. J. Autoimmun. 1: 445-467 (1988).

Schols, D., B. Vandekerckhove, D. Jones and M. G. RoncARoLo: IL-2 reverses human $T$ cell unresponsiveness induced by thymic epithelium in SCID-hu mice. J. Immunol. 152: 2198-2206 (1994).

Schultz, A.: Zell- und molekularbiologische Untersuchungen zur intrathymischen Pathogenese der paraneoplastischen Myasthenia gravis. Dissertation (1997).

Schultz, A., A. Greiner, R. Nenninger, D. Schömig, A. Wilisch, E. Oswald, R. A. KroczeK, B. Schalke, H. K. Müller-Hermelink and A. MarX: CD40 as a mediator of proliferation in normal and neoplastic thymic epithelium. Verh. Deut. Ges. Pathol. 80: 250-255 (1996).

SEIFERT, R. and B. Christ: On the differentiation and origin of myoid cells in the avian thymus. Anat. Embryol. Berl. 181: 287-298 (1990).

Singer, G. G. and A. K. AbBas: The fas antigen is involved in peripheral but not thymic deletion of $T$ lymphocytes in $\mathrm{T}$ cell receptor transgenic mice. Immunity 1: 365-371 (1994).

Singer, K. H., S. M. Denning, L. P. Whichard and B. F. HAYNES: Thymocyte LFA-1 and thymic epithelial cell ICAM-1 molecules mediate binding of activated human thymocytes to thymic epithelial cells. Immunol. 144: 2931-2939 (1990).

Sommer, N., N. Willcox, G. C. Harcourt and J. NewSom DAvis: Myasthenic thymus and thymoma are selectively enriched in acetylcholine receptor-reactive $\mathrm{T}$ cells. Ann. Neurol. 28: 312-319 (1990).

Sommer, N., G. C. Harcourt, N. Willcox, D. Beeson and J. Newsom Davis: Acetylcholine receptor-reactive $\mathrm{T}$ lymphocytes from healthy subjects and myasthenia gravis patients.

Spencer, J., M. Choy, T. Hussell, L. Papadaki, J. P. Kington and P. G. IsAacson: Properties of human thymic B cells. Immunology 75: 596-600 (1992).

Spits, H., L. L. Lanier and J. H. Phillips: Development of human T and natural killer cells. Blood 85: 2654-2670 (1995).

Surh, C. D. and J. Sprent: T-cell apoptosis detected in situ during positive and negative selection in the thymus [see comments]. Nature 372: 100-103 (1994).

SuRH, C. D., J. Sprent and S. R. WebB: Exclusion of circulating $\mathrm{T}$ cells from the thymus does not apply in the neonatal period. J. Exp. Med. 177: 379-385 (1993).

Swan, K. A., J. Alberola Ila, J. A. Gross, M. W. Appleby, K. A. Forbush, J. F. Thomas and R. M. PerlmutTer: Involvement of p21ras distinguishes positive and negative selection in thymocytes. EMBO. J. 14: 276-285 (1995).

Takahama, Y., J. J. Letterio, H. Suzuki, A. G. FarR and A. SINGER: Early progression of thymocytes along the $\mathrm{CD} 4 / \mathrm{CD} 8$ developmental pathway is regulated by a subset of thymic epithelial cells expressing transforming growth factor beta. J. Exp. Med. 179: 1495-1506 (1994). 
TAKeuchi, T., I. Kubonishi, Y. OHTSUkI and I. MiYoshi: A new monoclonal antibody to human subcapsular thymic epithelial cells. Virchows. Arch. A. Pathol. Anat. Histopathol. 419: 147-151 (1991).

Takeuchi, Y., Y. FuJi, M. OKumura, K. Inada, K. Nakahara and H. Matsuda: Accumulation of immature $\mathrm{CD} 3-\mathrm{CD} 4+\mathrm{CD} 8-$ single-positive cells that lack CD69 in epithelial cell tumors of the human thymus. Cell. Immunol. 161: 181-187 (1995).

Ting, C. N., M. C. Olson, K. P. Barton and J. M. LEIDEN : Transcription factor GATA-3 is required for development of the T-cell lineage. Nature 384: 474-478 (1996).

Utsumi, K., M. Sawada, S. NarumiYa, J. Nagamine, T. Sakata, S. Iwagami, Y. Kita, H. Teraoka, H. Hirano, M. OGATA, et al.: Adhesion of immature thymocytes to thymic stromal cells through fibronection molecules and its significance for the induction of thymocyte differentiation. Proc. Nat. Acad. Sci. U.S.A. 88: 56855689 (1991).

van de WiJngaert, F. P., L. H. Rademakers, H. J. Schuurman, R. A. DE Weger and L. Kater: Identification and in situ localization of the "thymic nurse cell" in man. J. Immunol. 130: 2348-2351 (1983).

van de WiJngaert, F. P., M. D. Kendall, H. J. SchuUrman, L. H. RAdemakers and L. Kater: Heterogeneity of epithelial cells in the human thymus. An ultrastructural study. Cell Tiss. Res. 237: 227-237 (1984).

van EWIJK, W., E. W. Shores and A. Singer: Crosstalk in the mouse thymus. Immunol. Today 15: 214-217 (1994).

van Oers, N. S. C., B. Lowin-Kropf, D. Finlay, K. Conolly and A. Weiss: $\alpha / \beta$ T cell development is abolished in mice lacking both Lck and Fyn protein tyrosine kinases. Immunity 5: 429-436 (1996).

VANDEKerckhove, B. A., R. Namikawa, R. BaCchetTa and M. G. Roncarolo: Human hematopoietic cells and thymic epithelial cells induce tolerance via different mechanisms in the SCID-hu mouse thymus. J. Exp. Med. 175: 1033-1043 (1992).

Vincent A.: Aetiological factors in development of myasthenia grabis. Adv. Neuroimmunol. 4: 355-371 (1994).

von Boenmer, H.: Positive selection of lymphocytes. Cell 76: 219-228 (1994).

von Gaudecker, B.: The development of the human thymus microenvironment. Curr. Top. Pathol. 75: 1-41 (1986).

von Gaudecker, B. and H. K. Müller-Hermelink: Ontogenetic differentiation of epithelial and non-epithelial cells in the human thymus. Adv. Exp. Med. Biol. 114: 19-23 (1979).

: Ontogeny and organization of the stationary non-lymphoid cells in the human thymus. Cell Tiss. Res. 207: 287-306 (1980).

Voss, S. D., R. Hong and P. M. Sondel: Severe combined immunodeficiency, interleukin-2 (IL-2), and the IL-2 receptor: experiments of nature continue to point the way [see comments]. Blood 83: 626-635 (1994).
Wang, C. R., K. Hashimoto, S. Kubo, T. Yoкосhi, M. Kubo, M. Suzuki, K. Suzuki, T. Tada and T. NakaYAMA: $T$ cell receptor-mediated signaling events in $\mathrm{CD} 4+\mathrm{CD} 8+$ thymocytes undergoing thymic selection: requirement of calcineurin activation for thymic positive selection but not negative selection. J. Exp. Med. 181: 927-941 (1995).

Weih, F., D. Carrasco, S. K. Durham, D. S. Barton, C. A. Rizzo, R. P. Ryseck, S. A. Lira and R. Bravo: Multiorgan inflammation and hematopoietic abnormalities in mice with a targeted disruption of RelB, a member of the NF-kappa B/Rel family. Cell 80: 331-340 (1995).

WekerLe, H. and U. P. Ketelsen: Intrathymic pathogenesis and dual genetic control of myasthenia gravis. Lancet 1: 678-680 (1977).

: Thymic nurse cells - Ia-bearing epithelium involved in T-lymphocyte differentiation? Nature 283: 402-404 (1980).

Wekerle, H., B. Paterson, U. Ketelsen and M. FeldMAN: Striated muscle fibres differentiate in monolayer cultures of adult thymus reticulum. Nature 256: 493-494 (1975).

Wekerle, H., U. P. Ketelsen, A. D. Zurn and B. W. FulPIUS: Intrathymic pathogenesis of myasthenia gravis: transient expression of acetylcholine receptors on thymus-derived myogenic cells. Eur. J. Immunol. 8: 579-582 (1978).

Wilisch, A., A. Schultz, A. Greiner, T. Kirchner, H. K. Müller-Hermelink and A. MarX: Molecular mimicry between neurofilaments and titin as the molecular basis of anti-striated muscle autoimmunity in paraneoplastic myasthenia gravis. Verh. Deut. Ges. Pathol. 80: 261-266 (1996).

Willcox, N., M. Schluep, M. A. RitTer, H. J. SchuUR man, J. Newsom Davis and B. Christensson: Myasthenic and nonmyasthenic thymoma. An expansion of a minor cortical epithelial cell subset? Amer. J. Pathol. 127: 447-460 (1987).

ZUTTER, M. M.: Immunolocalization of integrin receptors in normal lymphoid tissues. Blood 77: 2231-2236 (1991).

Prof. H. K. MÜLLER-HERMELINK
Department of Pathology
University of Würzburg
Josef Schneider Straße 2
D-97080 Würzburg
Germany

Prof. H. K. MÜLler-HermelinK D-97080 Würzburg 